\title{
Mononuclear gold catalysts for the asymmetric intramolecular hydroamination of alkenes.
}

\author{
Christophe Michon, ${ }^{*[a, b, c]}$ Marc-Antoine Abadie, ${ }^{[a, c]}$ Florian Medina, ${ }^{[a, c]}$ \\ Francine Agbossou-Niedercorn $*[a, b, c]$
}

\author{
[a] Dr. C. Michon, M.-A. Abadie, F. Medina, Dr. F. Agbossou-Niedercorn, \\ Université Lille Nord de France, 59000 Lille, France \\ [b]Dr. C. Michon, Dr. F. Agbossou-Niedercorn, CNRS, UCCS UMR 8181, 59655 Villeneuve d'Ascq, France \\ [c] Dr. C. Michon, M.-A. Abadie, F. Medina, Dr. F. Agbossou-Niedercorn, ENSCL, CCCF, (Chimie-C7) CS 90108 \\ 59652 Villeneuve d'Ascq Cedex, France, Phone : (+)33-320434893, (+)33-320434927, Fax: (+)33-320436585 \\ E-mail: christophe.michon@ensc-lille.fr,francine.agbossou@ensc-lille.fr
}

Supporting informations for this article are available on the web free of charge.

Keywords: hydroamination/ alkenes/ amines/ gold/ $N$-heterocycles

Abstract: The intramolecular gold catalyzed asymmetric hydroamination of alkenes was studied screening a series of mononuclear gold(I) and (III) complexes in combination with silver salts. Among the various chiral mono-phosphine and diaminocarbene ligands tried, the best catalysts arose from mononuclear gold(I) complexes synthesized from BINOL based phosphoramidite ligands. The latest were improved by addition of bulky substituents at specific positions of the BINOL scaffold. The resulting gold(I) complexes were combined with selected silver salts to afford efficient catalysts for intramolecular hydroamination of alkenes at mild temperatures, with good conversions and average enantioselectivities.

\section{Introduction.}

The hydroamination of unactivated alkenes is the shortest synthetic route to secondary and tertiary amines. [1] For the enantioselective synthesis of optically pure amines, the most studied and privileged hydroamination method is metal-catalysis. Lanthanides and actinides (f-block) were widely screened and significant achievements were reported for intramolecular reactions. [1b,c,g, 2] Group 4 metal (Zr, Ti) [1c, 3] or main-group metal (Mg, Li) [1c, 4] complexes led also to valuable results. By comparison, applications in asymmetric catalysis of transition metals from groups 3-11 (d-block) remain scarce but offer a broader functional group tolerance and substrate scope. [1c, 5, 81] Moreover, the development of recoverable catalysts may favour groups 3-11 metals which can lead to stable and easy to handle organometallic catalysts. 
Along the past years, the usefulness of gold [6] was pointed out on various C-C multiple bond substrates like alkynes, $[6,7]$ alkenes, $[6,8]$ allenes, $[6,9]$ and dienes $[6,10]$ for both intra- and intermolecular hydroamination reactions as well as for diaminations. These results may be quite surprising because gold(I) can be considered as a challenging metal for asymmetric catalysis. [11] First, it is stressed gold(I) privileges a linear-dicoordination geometry [12] which positions the ligand and the activated substrate in a trans fashion restricting thus the asymmetric induction. Tri and tetracoordination of gold(I) proved to be less common. [12, 13] Second, though the reaction mechanism appears to depend on the nature of the nucleophile, $[14,15]$ gold(I) catalyzed reactions are considered to be outer-sphere in most cases, the metal coordinating the substrate pi-system and the nucleophile attacking from the back side which is far away from the chiral ligand. However, some gold amide complexes were recently shown to be unreactive for the amination of alkynes suggesting that the inner sphere mechanism for addition to pi-bonds may not be preferred with some strong nucleophiles. [16a] In addition, it was also recently demonstrated that pi-bonds do not insert into the related gold-carbon bonds. [16b] Regarding the mechanisms of acid and gold catalyzed hydroamination of alkenes and dienes, Ujaque et al. have performed interesting calculations. [17] Whereas the acid-catalyzed process was shown as concerted, the gold-catalyzed reaction was found to be stepwise for the nucleophile-assisted and counterion-assisted pathways. Indeed, a proton-transfer agent, i.e the nucleophile or the counterion, was crucial to lower the energy barrier for the proton transfer step. Toste, Goddard et al. studied through calculations and experiments the intramolecular aminoauration of unactivated alkenes providing evidence of an anti-addition mechanism for alkene aminoauration. [18] However, once prepared, such assumed catalytic intermediates didn't allow the hydroamination reaction to proceed leading only to the unreacted alkenes. The authors concluded that was due to the high energy barrier calculated for the protodeauration step. [18]. Finally, the reversibility of C-Nuc bond formation was evidenced and may play an important role in the stereoselectivity of gold(I) catalyzed hydrofunctionalization. $[18,19]$

To date, 3 strategies have been developed in gold(I) catalyzed asymmetric catalysis and to some extent to hydroamination reactions. The first one implies the use of chiral phosphate anions like TRIP in combination with a gold(I) complex to create a tight ion pair. The resulting chiral binding pocket proved to be highly efficient for some asymmetric intramolecular hydroamination of allenes. [9ac, 9ad] The chiral phosphate counterion was shown to act as a ligand bonded to the gold species all along the hydroamination reaction. [20]

The second concept implies the use of chiral dinuclear gold(I)-phosphine complexes. Due to the broad choice of bisphosphine ligands, this approach has been versatile for some inter- and intramolecular asymmetric 
hydroamination of allenes and alkenes. [6, 8, 9] Surprisingly, little has been reported on the role of the second gold atom and the importance of gold-gold interactions in the catalytic course and therefore in the asymmetric induction. [8e]

The third strategy developed in gold(I) catalyzed asymmetric catalysis implies the use of mononuclear gold(I) complex relying mainly on chiral phosphoramidite and diaminocarbene ligands. Though that approach has been efficient for various asymmetric organic reactions, [6b, 21, 22, 23] it has until recently not been applied to hydroamination reactions and remains promising. [8a, 9i, 11, 24]

Though gold was shown to be active for intra- and inter-molecular hydroamination of alkenes, [6,8] high temperatures and long reaction times are generally required. Hence, asymmetric gold catalyzed hydroamination of alkenes has been scarcely studied with, to the best of our knowledge, only three specific reports published so far. First, Widenhoefer et al. reported on gold(I) catalyzed intermolecular hydroamination of ethylene and 1alkenes with cyclic ureas with good yields and enantioselectivities. [81] Second, Mikami et al. published on gold(I) catalyzed intramolecular hydroamination of $\mathrm{N}$-alkenyl ureas at room temperature with good yields and average enantioselectivities. [8e] Strikingly, these two studies relied on chiral dinuclear gold(I)-phosphine based catalysts. Mikami et al. assumed such species highly accelerated intramolecular hydroamination of $N$-alkenyl ureas via proximal and bimetallic activation of alkene and urea. According to the authors, rigid dinuclear gold complexes having $\mathrm{Au}-\mathrm{Au}$ interactions helped providing higher enantioselectivities. While the present work was nearing completion, a third report was published by Shi et al. about the preparation and the use of several monodentate axially-chiral $N$-heterocyclic carbene and phosphine ligands for mononuclear gold(I) catalyzed intramolecular hydroamination of $\mathrm{N}$-alkenyl tosylates. Moderate yields and enantioselectivities were obtained at quite high temperatures and reaction times. [8a] Interestingly, the authors studied their gold pre-catalysts by Xray diffraction analyses and identified a weak gold- $\pi$ interaction between the Au atom and one of the ligand aromatic ring. Presumably, such interaction might also occur with the gold cationic catalyst and influence the course of the reaction.

According to the previous statements, the achievement of efficient and highly selective gold catalyzed hydroamination of alkenes is still a challenging field. Hence, following our interest on hydroamination and azaMichael reactions[24,25] and considering the inadequacy of applications of chiral mononuclear gold(I) species to asymmetric hydroamination, [8a, 9f, 11, 24] we would like to report herein our own results on asymmetric intramolecular hydroamination of alkenes using mononuclear gold catalysts. 


\section{Results and discussion}

First, we performed preliminary studies on the racemic intramolecular hydroamination of alkene with amine substrates 1a-i using $\mathrm{Ph}_{3} \mathrm{PAuCl}$ as pre-catalyst along with 5 mol\% AgOTf (Table 1). Whereas electron rich amine substrates (entries 1-2) didn't afford any product, some electron poor substrates did. Indeed, $N$-alkenyl tosylate, benzylcarbamate and urea worked quite well (entries 3,6, 10). The use of pre-catalyst IPrAuCl instead of $\mathrm{Ph}_{3} \mathrm{PAuCl}$ increased significantly the product yield provided the alkene was not functionalized by any substituent (entries 7, 8, 9). Other $N$-alkenyl carboxamides proved to be non-reactive (entries 4,5 ). Hence, a strong substituent effect appeared controlling the intramolecular hydroamination reaction.

A first study on asymmetric intramolecular hydroamination of alkenes using mononuclear gold catalysts was then achieved by screening various chiral ligands and complexes for the reaction of reagent $\mathbf{1 f}$ (Table 2 and Figure 1). A catalytic amount of AgOTf was used along with each gold complex in order to generate in situ the cationic active species. As already reported, $N$-alkenyl carbamates proved to be privileged substrates when gold(I) catalysts were used. [8] In addition, as highlighted in the introduction of the present work, the carbamate function was shown to participate in a low barrier mechanistic hydroamination pathway through carbamate tautomerization assisted by a triflate anion acting as a proton shuttle. [17]

Table 1. Amine substitution effect on reactivity.

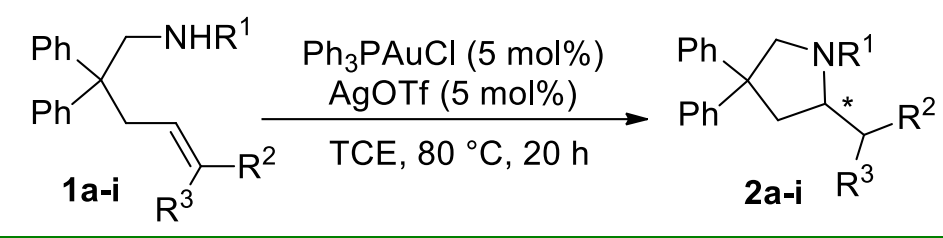

\begin{tabular}{cccccc}
\hline Entry & $\begin{array}{c}\text { Reagent } \\
\text { 1a-h }\end{array}$ & $\mathbf{R}^{\mathbf{1}}$ & $\mathbf{R}^{\mathbf{2}}$ & $\mathbf{R}^{\mathbf{3}}$ & $\begin{array}{c}\text { Product 7a-h } \\
\text { conversion }(\mathbf{\%})^{\boldsymbol{a}}\end{array}$ \\
\hline $1^{\mathrm{b}}$ & $\mathbf{1 a}$ & $\mathrm{Bn}$ & $\mathrm{H}$ & $\mathrm{H}$ & $0(\mathbf{2 a})$ \\
$2^{\mathrm{b}}$ & $\mathbf{1 b}$ & $\mathrm{CH}_{2} \mathrm{Cy}$ & $\mathrm{H}$ & $\mathrm{H}$ & $0(\mathbf{2 b})$ \\
3 & $\mathbf{1 c}$ & $\mathrm{Ts}$ & $\mathrm{H}$ & $\mathrm{H}$ & $>95(\mathbf{2 c})$ \\
4 & $\mathbf{1 d}$ & $\mathrm{Ac}$ & $\mathrm{H}$ & $\mathrm{H}$ & $0(\mathbf{2 d})$ \\
5 & $\mathbf{1 e}$ & $\mathrm{Bz}$ & $\mathrm{H}$ & $\mathrm{H}$ & $0(\mathbf{2 e})$ \\
6 & $\mathbf{1 f}$ & $\mathrm{CBz}$ & $\mathrm{H}$ & $\mathrm{H}$ & $50(\mathbf{2 f})$ \\
$7^{\mathrm{c}}$ & $\mathbf{1 f}$ & $\mathrm{CBz}$ & $\mathrm{H}$ & $\mathrm{H}$ & $90(\mathbf{2 f})$ \\
$8^{\mathrm{c}}$ & $\mathbf{1 g}$ & $\mathrm{CBz}$ & $\mathrm{Me}$ & $\mathrm{H}$ & $0(\mathbf{2 g})$ \\
$9^{\mathrm{c}}$ & $\mathbf{1 h}$ & $\mathrm{CBz}$ & $\mathrm{Me}$ & $\mathrm{Me}$ & $0(\mathbf{2 h})$ \\
10 & $\mathbf{1 i}$ & $\mathrm{CONHPh}$ & $\mathrm{H}$ & $\mathrm{H}$ & $>95(\mathbf{2 i})$ \\
\hline
\end{tabular}

${ }^{a}$ Measured by NMR ${ }^{1} \mathrm{H} .{ }^{b}$ Same result at $120{ }^{\circ} \mathrm{C} .{ }^{c}$ with $5 \mathrm{~mol} \% \mathrm{IPrAuCl}$ instead of $\mathrm{Ph}_{3} \mathrm{PAuCl}$. 
Our screening started with mononuclear gold(I) complexes $\mathbf{3}$ and $\mathbf{5}$ based on diaminocarbene ligands [23] but poor conversions and enantioselectivities were obtained (Figure 1 and Table 2 entries 1, 3). Gold(III) diaminocarbene complexes 4 and 6 [24] didn't afford any reaction (Scheme 1 and Table 2, entries 2, 4). We next switched to mononuclear gold(I) complexes issued from phosphoramidite ligands (Figure 1, table 2). First, $\mathbf{L}_{1}$ based on BINOL and the Whitesell amine was used affording product $\mathbf{2} \mathbf{f}$ in good conversions and moderate enantioselectivities (Table 2, entries 5-7). The stereoselectivity as well as the catalyst activity proved to strongly depend on the ligand configuration. Indeed, the chirality of the BINOL scaffold and of the amine needed to be opposite to afford the best results, $(R, S, S)$ and $(S, R, R)$ being the configurations of choice. Next, as shown by the use of phosphoramidite ligands $\mathbf{L}_{2}-\mathbf{L}_{5}$, any change on the chiral amine fragment proved to have a negative effect on the enantioselectivity (table 2, entries 8-11). Moreover, the switch from ligand Monophos $\mathbf{L}_{5}$ to $\mathbf{L}_{6}$, that is to say the change from a BINOL scaffold to a partially hydrogenated one, led to a severe decrease of the conversion (entries 11-12). Hence, an increase of the ligand dihedral angle had a negative effect on the reactivity. In addition, the change to ligand $\mathbf{L}_{8}$ based on a biphenyl scaffold resulted in a decrease of the enantioselectivity (entrie 14). Such a trend was also observed when the ligand BINOL backbone was

Table 2. Screening of mononuclear gold(I) and (III) catalysts.

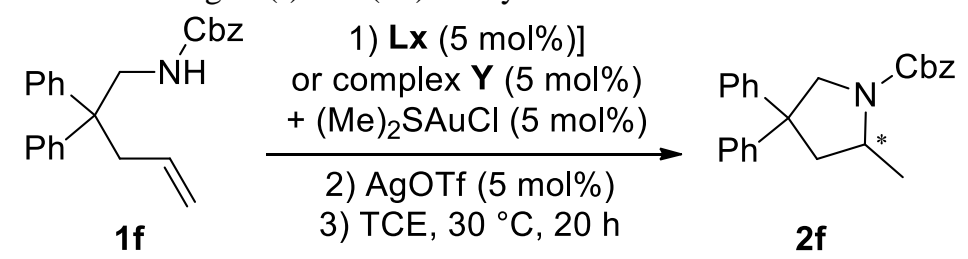

\begin{tabular}{|c|c|c|c|c|}
\hline Entry & $\begin{array}{c}\text { Ligand }(\mathbf{L x}) \text { or } \\
\text { complex }(\mathbf{Y}) \\
\end{array}$ & Conversion $^{a}(\%)$ & $\operatorname{Ee}(\%)^{b}$ & Configuration $^{c}$ \\
\hline $1^{d}$ & $(R, R)-3$ & 5 & 4 & $(S)$ \\
\hline $2^{e, f}$ & $(R, R)-4$ & 0 & 0 & - \\
\hline $3^{g}$ & $(R, R)-5$ & 9 & 5 & $(S)$ \\
\hline 4 & $(S, S)-6$ & 0 & 0 & - \\
\hline 5 & $(S, R, R)-\mathrm{L}_{1}$ & 75 & 15 & $(R)$ \\
\hline 6 & $(S, S, S)-\mathrm{L}_{1}$ & $<5$ & - & - \\
\hline 7 & $(R, S, S)-\mathrm{L}_{1}$ & 62 & 19 & $(S)$ \\
\hline 8 & $(S, R)-\mathbf{L}_{2}$ & 70 & 5 & $(S)$ \\
\hline 9 & $(S, R, R)-\mathrm{L}_{3}$ & 85 & 4 & $(R)$ \\
\hline 10 & $(R, R, R)-\mathbf{L}_{4}$ & $>95$ & 7 & $(S)$ \\
\hline 11 & $(R)-\mathbf{L}_{5}$ & 90 & 6 & $(S)$ \\
\hline 12 & $(S)-\mathrm{L}_{6}$ & 15 & 4 & $(R)$ \\
\hline 13 & $(S)-\mathrm{L}_{7}$ & $>95$ & 1 & $(S)$ \\
\hline 14 & $(S, S)-\mathrm{Ls}_{8}$ & 90 & 12 & $(S)$ \\
\hline 15 & $(R, R, R)-\mathrm{L} 9$ & 90 & 7 & $(R)$ \\
\hline 16 & $(R, R)-\mathrm{L}_{10}$ & $>95$ & 8 & $(R)$ \\
\hline
\end{tabular}

${ }^{a}$ Measured by ${ }^{1} \mathrm{H}$ NMR. ${ }^{b}$ Measured by HPLC at $204 \mathrm{~nm} .{ }^{c}$ Determined from HPLC by comparison with previous work (see supporting information). ${ }^{d}$ Performed at $80{ }^{\circ} \mathrm{C}$ for $20 \mathrm{~h}$. ${ }^{e}$ Same result using $\mathrm{AgBF}_{4}$ at $100{ }^{\circ} \mathrm{C}$ for 20 h. ${ }^{f}$ Same result using $\mathrm{AgSbF}_{6}$ at $100{ }^{\circ} \mathrm{C}$ in dioxane or at $60{ }^{\circ} \mathrm{C}$ in THF. ${ }^{g}$ Performed at $130{ }^{\circ} \mathrm{C}$ for $24 \mathrm{~h}$. 
substituted at the 3,3'-positions by two methyl substituents $\left(\mathbf{L}_{7}\right)$ (entries 11,13). The spiro phosphoramidite ligand $\mathbf{L} 9$ and the taddol based ligand $\mathbf{L}_{10}$ afforded high conversions but low ee (entries 15-16).

Figure 1. Ligands and complexes used for the screening of mononuclear gold(I) and (III) catalysts.

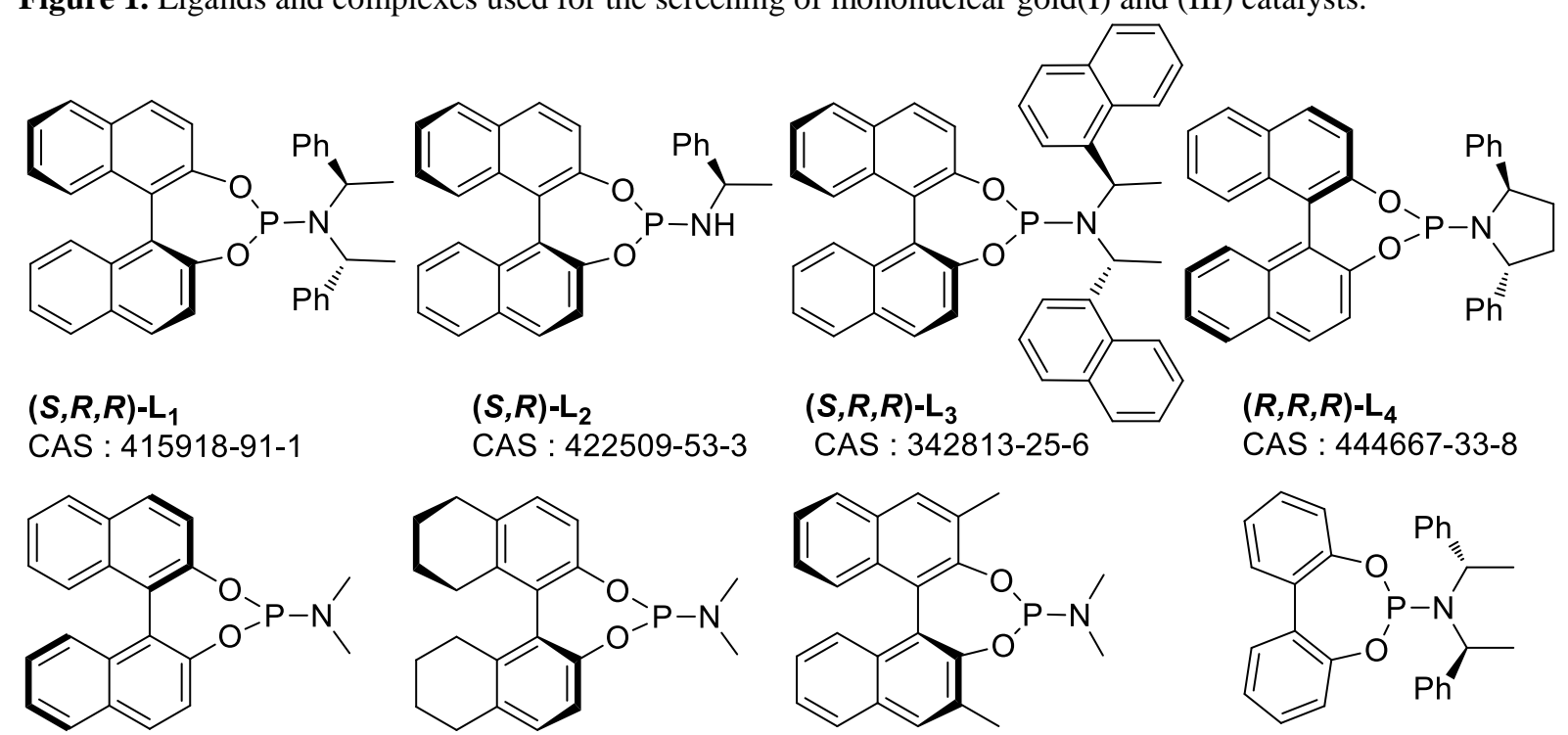

$(R)-L_{5}$

CAS : $157488-65-8$<smiles></smiles>

$(R, R, R)-L_{9}$

CAS : 500997-69-3
(S) $-\mathrm{L}_{6}$

CAS : 389130-06-7<smiles>CN(C)P1OC(c2ccccc2)(c2ccccc2)C2OC(C)(C)OC2C(c2ccccc2)(c2ccccc2)O1</smiles>

$(R, R)-L_{10}$

CAS : 213843-90-4
(S)- $\mathrm{L}_{7}$

CAS : 185449-86-9<smiles>[M]C1N(c2ccccc2OC)[C@H](c2ccccc2)[C@@H](c2ccccc2)N1c1ccccc1OC</smiles>

$(\boldsymbol{R}, \boldsymbol{R})-3 \mathrm{M}=\mathrm{AuCl}$

$(\boldsymbol{R}, \boldsymbol{R})-4 \mathrm{M}=\mathrm{AuCl}_{3}$
$(S, S)-L_{8}$

CAS : 376355-58-7<smiles>[M]C1N(C(c2ccccc2)c2ccccc2)C(c2ccccc2)C(c2ccccc2)N1C(c1ccccc1)c1ccccc1</smiles>

$(\boldsymbol{R}, \boldsymbol{R})-5 \mathrm{M}=\mathrm{AuCl}$

$(S, S)-6 \mathrm{M}=\mathrm{AuCl}_{3}$

By comparison to mononuclear gold(I) catalysts, dinuclear gold(I) catalysts didn’t afford better conversions and enantioselectivities within the same experimental conditions (Table 3 and Figure 2). A maximum of $70 \%$ conversion was reached with biphep ligand $\mathbf{L} 15$ along with a poor enantioselectivity (Table 3, entry 1). Surprisingly, the change for L16 with a Segphos backbone led to complete loss of reactivity (entry 2). The use of trans-ligands $\mathbf{L}_{17}$ and $\mathbf{L}_{18}$ (entries 3-4) or P-chiral phosphines $\mathbf{L}_{19}$ and $\mathbf{L}_{20}$ (entries 5-6) afforded $\mathbf{2 f}$ in low conversions with no enantioselectivity.

We next checked the anion influence on the conversion and enantiomeric excess (Table 4). Among the various silver salts screened (entries 1-10), tetrafluoroborate and perchlorate anions appeared to be the most appropriate (entries 3,6). Hence, in our reaction conditions, a strong ion-pairing implied a good conversion and a higher enantioselectivity for product 2f. Moreover, when no ligand and gold were used, silver tetrafluoroborate was not 
Table 3. Screening of binuclear gold(I).

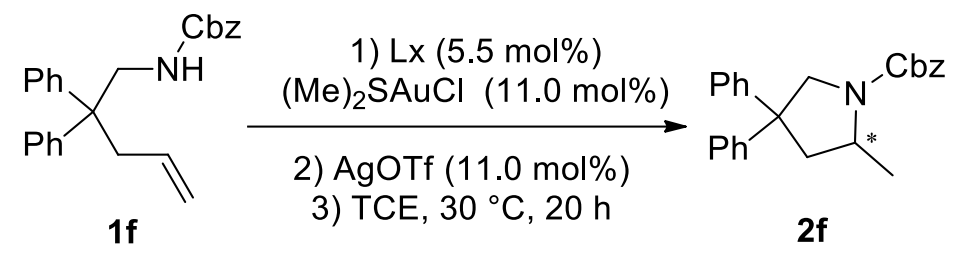

\begin{tabular}{ccccc}
\hline Entry & Ligand (Lx) & Conversion $^{a}(\%)$ & Ee $(\%)^{b}$ & Configuration $^{c}$ \\
\hline $1^{d}$ & $(\boldsymbol{S})-\mathbf{L}_{15}$ & 70 & 5 & $(R)$ \\
2 & $(\boldsymbol{S})-\mathbf{L}_{16}$ & 5 & - & - \\
3 & $(\boldsymbol{S})-\mathbf{L}_{17}$ & 5 & - & - \\
$4^{d}$ & $(\boldsymbol{R}, \boldsymbol{R})-\mathbf{L}_{18}$ & 35 & 5 & $(S)$ \\
$5^{e}$ & $(\boldsymbol{R}, \boldsymbol{R})-\mathbf{L}_{19}$ & 20 & 0 & - \\
$6^{e}$ & $(\boldsymbol{R}, \boldsymbol{R})-\mathbf{L}_{20}$ & 25 & 0 & - \\
\hline
\end{tabular}

${ }^{a}$ Measured by ${ }^{1} \mathrm{H}$ NMR. ${ }^{b}$ Measured by HPLC at $204 \mathrm{~nm}$.

${ }^{c}$ Determined from HPLC by comparison with previous work (see supporting information).

${ }^{d}$ Performed at $80{ }^{\circ} \mathrm{C} .{ }^{e}$ Performed with $2.5 \mathrm{~mol} \%$ ligand and $5 \mathrm{~mol} \%(\mathrm{Me})_{2} \mathrm{SAuCl}$.

Figure 2. Ligands used for the screening of binuclear gold(I) catalysts.<smiles>COc1cccc(Pc2cccc(OC)c2-c2c(Pc3cc(CC(C)(C)C)c(OC)c(C(C)(C)C)c3)cccc2C(C)(C)C)c1OC</smiles>

$(S)-L_{15}$

CAS : $910134-30-4$

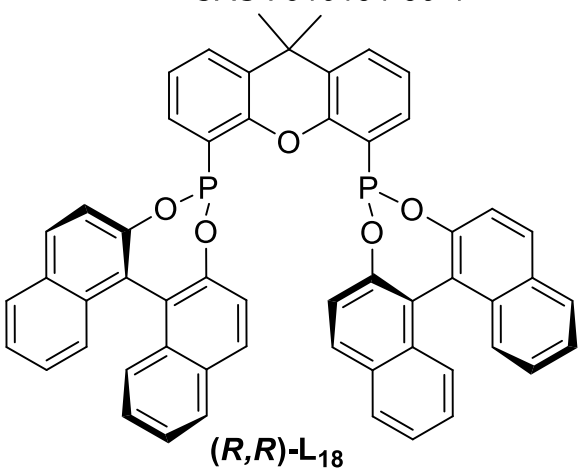

CAS : $349114-63-2$<smiles>COc1c(C(C)(C)C)cc(Pc2ccc3c(c2-c2c(P(C)c4cc(C(C)(C)C)c(OC)c(C(C)(C)C)c4)ccc4c2OCO4)OCO3)cc1C(C)(C)C</smiles>

(S) $-\mathrm{L}_{16}$

CAS : $210169-40-7$<smiles>COc1ccccc1P(CCP(c1ccccc1)c1ccccc1OC)c1ccccc1</smiles>

$(R, R)-\mathrm{L}_{19}$ CAS : $55739-58-7$

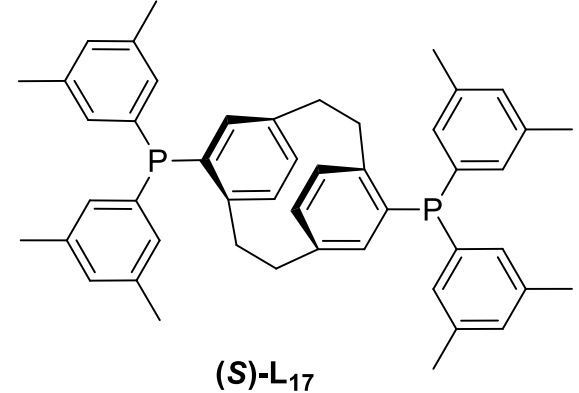

CAS : 325168-88-5

$(R, R)-\mathrm{L}_{20}$

CAS : $866081-62-1$

catalysing the hydroamination of 1a (entrie 4). Gold(I) catalyst based on L1 proved to be non-reactive when associated with chiral TRIP phosphate anion, even if stronger reaction conditions were used (entries 9-10).

To pursue our study on the influence of reaction parameters, various solvents were screened (Table 5). Except for tetrachloroethane and dioxane (entries 1, 7), reaction was not running in polar solvents (entries 9-12). Though reactions needed to be heated, apolar aromatic solvents afforded $\mathbf{2} \mathbf{f}$ in better conversions and enantiomeric excesses (entries 2-6,8). On that basis, we confirmed tight ion pairs were critical to allow the reaction to proceed 
enantioselectively. Moreover, the reaction outcome remained unchanged upon removal of $\mathrm{AgCl}$ by filtration through Celite ${ }^{\mathrm{TM}}$ of the phosphoramidite mononuclear gold(I) cationic species prepared prior to the catalysis (entry 2). Hence, no "silver effect" was observed in our gold catalysed hydroamination reactions. [26, 26d]

Table 4. Silver salt screening.

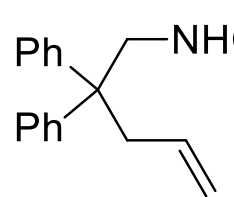

$1 f$

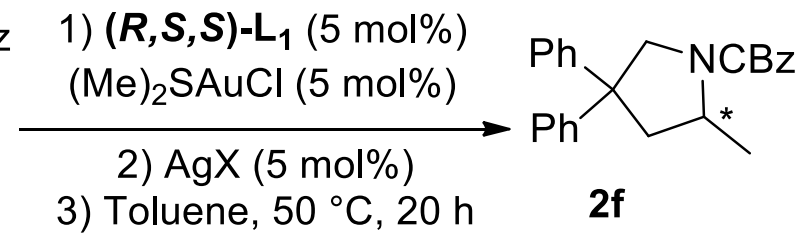

\begin{tabular}{lcccc}
\hline Entry & AgX & Conversion $(\%)^{a}$ & $\mathbf{E e ~ ( \% )}$ & Configuration $^{c}$ \\
\hline 1 & AgOTf & 75 & 23 & $(S)$ \\
2 & AgOTs & 10 & - & - \\
3 & ggBF $_{4}$ & $>95$ & 27 & $(S)$ \\
$4^{d}$ & $\mathrm{AgBF}_{4}$ & 0 & - & - \\
5 & $\mathrm{AgSbF}_{6}$ & $>95$ & 18 & $(S)$ \\
6 & $\mathrm{AgClO}_{4}$ & $>95$ & 27 & $(S)$ \\
7 & $\mathrm{AgNTf}_{2}$ & 10 & 11 & $(S)$ \\
$8^{e}$ & $\mathrm{AgBARF}^{e}$ & $<5$ & - & - \\
$9^{e}$ & $(R)$-AgTRIP & $<5$ & - & - \\
$10^{e}$ & $(S)$-AgTRIP & $<5$ & - & - \\
\hline \multicolumn{5}{c}{${ }^{a}$ Measured by ${ }^{1} \mathrm{H} \mathrm{NMR.}^{b}$ Measured by HPLC at $204 \mathrm{~nm}}$.
\end{tabular}

${ }^{c}$ Determined from HPLC by comparison with previous work (see supporting information).

${ }^{d}$ Performed without any ligand and gold source. ${ }^{e}$ Done with $(S, R, R)-\mathbf{L} \mathbf{1}$.

Table 5. Solvent screening.

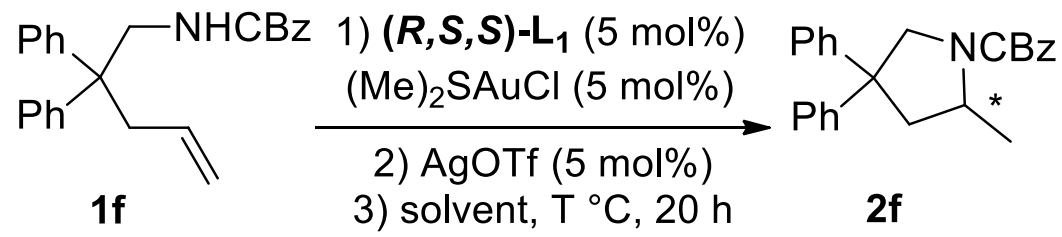

\begin{tabular}{cccccc}
\hline Entry & Solvent & $\begin{array}{c}\mathbf{T} \\
\left({ }^{\circ} \mathbf{C}\right)\end{array}$ & $\begin{array}{c}\text { Conversion } \\
(\boldsymbol{\%})^{\boldsymbol{a}}\end{array}$ & $\begin{array}{c}\text { Ee } \\
(\boldsymbol{\%})^{b}\end{array}$ & Configuration $^{c}$ \\
\hline $1^{d}$ & TCE & 30 & 75 & 15 & $(S)$ \\
$2^{e}$ & Toluene & 50 & 75 & 23 & $(S)$ \\
$3^{f}$ & Toluene & 50 & 50 & 23 & $(S)$ \\
4 & Toluene & 30 & 0 & - & - \\
5 & Toluene & 70 & 95 & 20 & $(S)$ \\
6 & Benzene & 50 & 0 & - & - \\
7 & 1,4-dioxane & 50 & 20 & 19 & $(S)$ \\
8 & m-xylene & 50 & $<10$ & - & - \\
9 & THF & 50 & $<5$ & - & - \\
10 & $\mathrm{CH}_{2} \mathrm{Cl}{ }_{2}$ & 30 & $<5$ & - & - \\
11 & $\mathrm{CF}_{3} \mathrm{CH}_{2} \mathrm{OH}$ & 50 & $<5$ & - & - \\
12 & $\mathrm{CH}_{3} \mathrm{CN}$ & 50 & $<5$ & - & - \\
\hline
\end{tabular}

${ }^{a}$ Measured by ${ }^{1} \mathrm{H}$ NMR. ${ }^{b}$ Measured by HPLC at $204 \mathrm{~nm}$.

${ }^{c}$ Determined from HPLC by comparison with previous work (see supporting information).

${ }^{d}$ Done with $(S, R, R)-\mathbf{L}_{\mathbf{1}}{ }^{e}$ Same result using a catalyst purified by filtration over Celite ${ }^{\mathrm{TM}}$.

${ }^{f} 1$ equivalent of water was added as soon as the reaction was started. 
In addition, because all experiments were carried out under nitrogen and strict conditions (see experimental part), our gold-triflate catalysts were unlikely to form any hydrate or hydroxide species along the hydroamination reactions. [26c] We noticed the voluntary addition of 1 equivalent of water to the reaction mixture resulted in a conversion decrease without any change on the enantioselectivity (Table 5, entry 3 ).

Next, using selected experimental conditions, we reinvestigated the substituent effect on amine reactivity (Table 6). All reactions afforded good to high conversions in $20 \mathrm{~h}$ at $50{ }^{\circ} \mathrm{C}$ or below. However, mononuclear gold(I) catalyst based on phosphoramidite ligand L1 appeared to be sensitive to alkene substituents, because substrate $1 \mathrm{~g}$ didn’t react even when the reaction was heated at $100^{\circ} \mathrm{C}$ (entry 4). Regarding the enantioselectivity, $N$-alkenyl $\mathrm{CBz}$ and urea were by far the most appropriate substrates with values respectively of 23 and $30 \%$ ee provided the reaction temperature was set to $50^{\circ} \mathrm{C}$ and the solvent was toluene (entries $1-3,13,14$ ). The $N$-tosyl and Boc substrates reacted only in tetrachloroethane and led to no enantioselectivity (entries 9-12). The change of substituents at the $\mathrm{C} 2$ position of the alkenyl chain had even a more critical effect on the reactivity and stereochemical outcome of the hydroamination reaction. Indeed, conversions and enantioselectivities were very low for methyl and cyclohexyl substituents (entries 5-7,15). Such trend was also observed for substrate 11 with a 5-hexenyl chain (entry 8).

Table 6. Substituent effects on enantioselectivity.

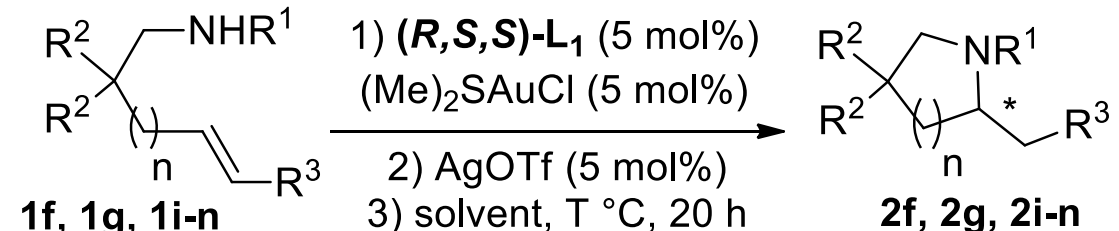

\begin{tabular}{|c|c|c|c|c|c|c|c|c|c|}
\hline Entry & Reagent & $\mathbf{N}$ & $\mathbf{R}^{1}$ & $\mathbf{R}^{2}$ & $\mathbf{R}^{3}$ & Solvent & $\mathbf{T}\left({ }^{\circ} \mathbf{C}\right)$ & $\begin{array}{c}\text { Conversion } \\
(\%)^{a}\end{array}$ & $\begin{array}{c}\mathbf{E e} \\
(\%)^{b}\end{array}$ \\
\hline $1^{\mathrm{c}}$ & 1f & 1 & $\mathrm{CBz}$ & $\mathrm{Ph}$ & $\mathrm{H}$ & toluene & 50 & 2f 75 & 23 \\
\hline 2 & 1f & 1 & $\mathrm{CBz}$ & $\mathrm{Ph}$ & $\mathrm{H}$ & TCE & 30 & 2f 75 & 15 \\
\hline 3 & 1f & 1 & $\mathrm{CBz}$ & $\mathrm{Ph}$ & $\mathrm{H}$ & toluene & 30 & 2f 75 & 15 \\
\hline $4^{c}$ & $1 g$ & 1 & $\mathrm{CBz}$ & $\mathrm{Ph}$ & $\mathrm{Me}$ & toluene & 100 & $2 \mathrm{~g} 0$ & - \\
\hline $5^{\mathrm{d}}$ & $\mathbf{1 j}$ & 1 & $\mathrm{CBz}$ & $\mathrm{Me}$ & $\mathrm{H}$ & TCE & 50 & $2 \mathbf{j} 20$ & 0 \\
\hline $6^{e, f}$ & $\mathbf{1 j}$ & 1 & $\mathrm{CBz}$ & $\mathrm{Me}$ & $\mathrm{H}$ & toluene & 50 & $2 \mathbf{j} 0$ & - \\
\hline $7^{\mathrm{e}}$ & $1 \mathrm{k}$ & 1 & $\mathrm{CBz}$ & $-\left(\mathrm{CH}_{2}\right)_{4-}$ & $\mathrm{H}$ & toluene & $50(20 \mathrm{~h})$ & 2k 10 & - \\
\hline $8^{c}$ & 11 & 2 & $\mathrm{CBz}$ & $\mathrm{Ph}$ & $\mathrm{H}$ & toluene & 100 & 210 & - \\
\hline $9^{e, f}$ & 1c & 1 & Tos & $\mathrm{Ph}$ & $\mathrm{H}$ & toluene & 50 & $2 \mathrm{~m} 0$ & - \\
\hline 10 & $1 c$ & 1 & Tos & $\mathrm{Ph}$ & $\mathrm{H}$ & $\mathrm{TCE}$ & 80 & $2 \mathrm{~m}>95$ & 0 \\
\hline $11^{\mathrm{e}, \mathrm{f}}$ & $1 \mathrm{~m}$ & 1 & Boc & $\mathrm{Ph}$ & $\mathrm{H}$ & toluene & 50 & 2n 0 & - \\
\hline $12^{\mathrm{e}}$ & $1 \mathrm{~m}$ & 1 & Boc & $\mathrm{Ph}$ & $\mathrm{H}$ & TCE & 50 & 2n 23 & 1 \\
\hline $13^{\mathrm{e}}$ & $\mathbf{1 i}$ & 1 & CONHPh & $\mathrm{Ph}$ & $\mathrm{H}$ & toluene & 50 & $2 \mathbf{i}>95$ & $30^{\mathrm{g}}$ \\
\hline $14^{\mathrm{e}}$ & 1i & 1 & CONHPh & $\mathrm{Ph}$ & $\mathrm{H}$ & TCE & 50 & $2 \mathbf{i}>95$ & 18 \\
\hline $15^{\mathrm{e}, \mathrm{h}}$ & 1n & 1 & CONHPh & $\mathrm{Me}$ & $\mathrm{H}$ & toluene & 50 & 2075 & 12 \\
\hline
\end{tabular}

${ }^{a}$ Measured by ${ }^{1} \mathrm{H}$ NMR. ${ }^{b}$ Measured by HPLC at $204 \mathrm{~nm} .{ }^{c}$ Same result at $100{ }^{\circ} \mathrm{C}$ for $20 \mathrm{~h} .{ }^{d}$ Done at $50{ }^{\circ} \mathrm{C}$ for 87 h. ${ }^{e}$ Performed with $(S, R, R)-\mathrm{L}_{1} \cdot{ }^{f}$ Same result at 80 or $100{ }^{\circ} \mathrm{C} .{ }^{g}$ Same result at $0{ }^{\circ} \mathrm{C} .{ }^{h}$ Done with $\mathrm{AgClO}_{4}$. 
Considering our results and the general trends in gold(I) catalyzed asymmetric reactions, [21] a series of phosphoramidite ligands related to $\mathbf{L}_{1}$ was foreseen. Based on the Whitesell amine and on BINOL, these ligands would carry bulky substituents at the 3,3' positions of the BINOL scaffold (see Figure 3 and Table 7). [27] As illustrated by some MM2 calculations, we were confident such phosphoramidite ligands would afford an enhanced steric hindrance around the gold(I) catalytic center and would lead to a better enantioselectivity (see supporting information). All the 3,3'-substituted phosphoramidite ligands of defined configurations (Figure 3) were prepared according reported procedures (see supporting information). Catalytic tests were performed on substrates 1f, 1i-k and $\mathbf{1 n}$ performing first the reactions with our best experimental conditions, in toluene at 50 ${ }^{\circ} \mathrm{C}$ for $20 \mathrm{~h}$ using $\mathrm{AgClO}_{4}$ (Table 7, Figure 3).

Figure 3. Tuned phosphoramidite ligands used for the screening of mononuclear gold(I) catalyst.<smiles>CC(c1ccccc1)N(C(C)c1ccccc1)p1oc2ccc3ccccc3c2c2c(ccc3ccccc32)o1</smiles>

$(S, R, R)-\mathrm{L}_{1}$ CAS : 415918-91-1<smiles>C[C@H](c1ccccc1)N([C@H](C)c1ccccc1)P(Oc1ccccc1)Oc1c(-c2ccccc2)cc2ccccc2c1-c1c(-c2ccc(-c3ccccc3)cc2)cc2ccccc2c1OP</smiles><smiles>c1ccc2cc3ccccc3cc2c1</smiles>

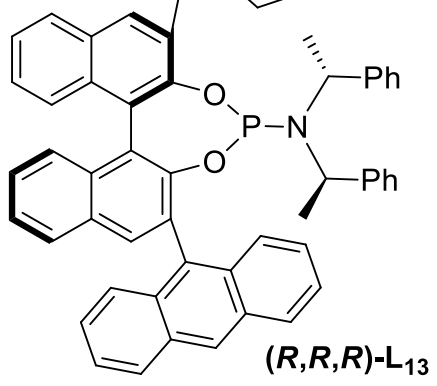

$(R, R, R)-\mathrm{L}_{13}$<smiles>CC(c1ccccc1)N(C(C)c1ccccc1)p1oc2c(-c3ccccc3)cc3ccccc3c2c2c(-c3ccccc3)cc3ccccc3c2o1</smiles>

$(S, S, S)-L_{11}$

$(S, R, R)-\mathrm{L}_{11}$<smiles></smiles><smiles>C[C@H](c1ccccc1)N([C@H](C)c1ccccc1)p1oc2cc3ccccc3c(-c3ccccc3)c2c2c(o1)c(-c1c3ccccc3cc3ccccc13)cc1ccccc12</smiles><smiles>CC(c1ccccc1)N(C(C)c1ccccc1)p1oc2c(-c3ccccc3)cc3ccccc3c2c2c(-c3ccccc3)cc3ccccc3c2o1</smiles>

$(R, R, R)-\mathrm{L}_{11}$

$(R, S, S)-\mathrm{L}_{11}$<smiles>CC(c1ccccc1)N(C(C)c1ccccc1)P(Oc1ccccc1)Oc1c(C(c2ccccc2)c2ccccc2)cc2ccccc2c1-c1cc2ccccc2cc1C(c1ccccc1)c1ccccc1</smiles>

$(S, R, R)-L_{14}$<smiles>CC(c1ccccc1)N(C(C)c1ccccc1)P(Oc1ccccc1)Oc1c(C(c2ccccc2)c2ccccc2)cc2ccccc2c1-c1cc2ccccc2cc1C(c1ccccc1)c1ccccc1</smiles>

$(R, S, S)-L_{14}$

$(S, R, R)-L_{14}$ $(S, S, S)-L_{14}$

The use of phosphoramidite ligand $\mathbf{L}_{\mathbf{1}}$ confirmed the enhanced ee previously obtained (entry 1 ). We next studied the four stereoisomers of phosphoramidite ligand $\mathbf{L}_{11}$ bearing phenyl substituents. Conversions were almost quantitative but enantioselectivities highly depended on the ligand configuration, values being quite disparate 
(entries 2-5). With a $95 \%$ conversion and a $28 \%$ ee, ligand $(\boldsymbol{S}, \boldsymbol{R}, \boldsymbol{R})-\mathbf{L}_{11}$ afforded the best result (entry 4). Lowering the temperature to $0{ }^{\circ} \mathrm{C}$ didn't improve $\mathbf{2 f}$ enantioselectivity and reduced significantly the conversion (entry 6). It was worth noting the chirality of L11 BINOL fragment was the key factor controlling the stereochemistry of the product $\mathbf{2 f}$. Indeed, both were shown to display the same configuration. However, this trend could not be observed for other phosphoramidite ligands $\mathbf{L}_{\mathbf{1 2}}, \mathbf{L}_{\mathbf{1 3}}$ and $\mathbf{L}_{\mathbf{1 4}}$ (entries 7-13). Ligand $\mathbf{L}_{\mathbf{1 2}}$ bearing biphenyl substituents afforded product $\mathbf{2 f}$ in high $95 \%$ conversions and average $29 \%$ ee provided $(\boldsymbol{R}, \boldsymbol{S}, \boldsymbol{S})$-L12 was used (entries 7, 8). Phosphoramidite ligand $\mathbf{L}_{13}$ functionalized by anthracenyl substituents led also to high conversions (95\%) but lower ee (16-18\%) were obtained (entries 9, 10).

Table 7. Screening of mononuclear gold(I) catalyst based on tuned phosphoramidite ligands.

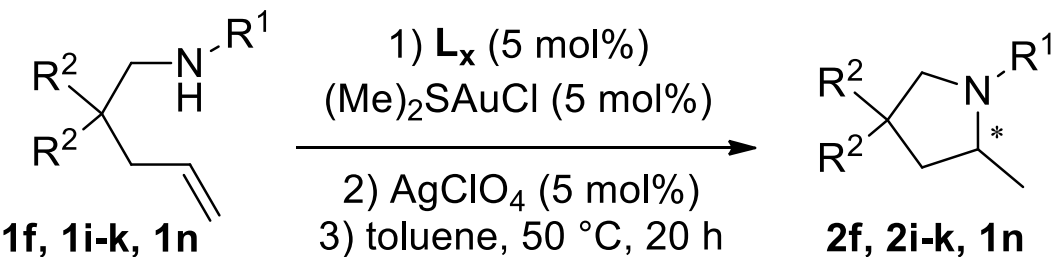

\begin{tabular}{|c|c|c|c|c|c|c|c|}
\hline Entry & Reagent & $\mathbf{R}^{1}$ & $\mathbf{R}^{2}$ & $\begin{array}{l}\text { Ligand } \\
\text { (Lx) }\end{array}$ & $\begin{array}{c}\text { Conversion }^{a} \\
(\%)\end{array}$ & $\begin{array}{c}\text { Ee } \\
(\%)^{b}\end{array}$ & Configuration $^{c}$ \\
\hline 1 & 1f & CBz & $\mathbf{P h}$ & $(S, R, R)-\mathrm{L}_{1}$ & $2 f>95$ & 21 & $(R)$ \\
\hline 2 & 1f & $\mathrm{CBz}$ & $\mathbf{P h}$ & $(S, S, S)-\mathrm{L}_{11}$ & $2 f>95$ & 11 & $(S)$ \\
\hline 3 & 1f & $\mathbf{C B z}$ & $\mathbf{P h}$ & $(R, R, R)-L_{11}$ & $2 f>95$ & 7 & $(R)$ \\
\hline 4 & 1f & $\mathbf{C B z}$ & $\mathbf{P h}$ & $(S, R, R)-\mathbf{L}_{11}$ & 2f $>95$ & 28 & $(S)$ \\
\hline 5 & 1f & $\mathrm{CBz}$ & $\mathbf{P h}$ & $(R, S, S)-L_{11}$ & $2 f>95$ & 15 & $(R)$ \\
\hline $6^{d}$ & 1f & $\mathbf{C B z}$ & $\mathbf{P h}$ & $(R, S, S)-\mathrm{L}_{11}$ & 2f 35 & 14 & $(R)$ \\
\hline 7 & 1f & $\mathbf{C B z}$ & $\mathbf{P h}$ & $(R, S, S)-\mathbf{L}_{12}$ & $\mathbf{2 f}>95$ & 29 & $(R)$ \\
\hline 8 & 1f & $\mathbf{C B z}$ & $\mathbf{P h}$ & $(R, R, R)-\mathrm{L}_{12}$ & 2f $>95$ & 3 & $(S)$ \\
\hline 9 & 1f & $\mathrm{CBz}$ & Ph & $(R, R, R)-\mathbf{L}_{13}$ & $2 f>95$ & 16 & $(R)$ \\
\hline 10 & 1f & $\mathrm{CBz}$ & $\mathbf{P h}$ & $(R, S, S)-\mathrm{L}_{13}$ & $\mathbf{2 f}>95$ & 18 & $(R)$ \\
\hline 11 & 1f & $\mathbf{C B z}$ & $\mathbf{P h}$ & $(S, S, S)-\mathrm{L}_{14}$ & $2 f>95$ & 13 & $(S)$ \\
\hline 12 & 1f & $\mathrm{CBz}$ & $\mathbf{P h}$ & $(S, R, R)-\mathbf{L}_{14}$ & $2 f>95$ & 2 & $(S)$ \\
\hline 13 & 1f & $\mathrm{CBz}$ & $\mathbf{P h}$ & $(R, S, S)-\mathbf{L}_{14}$ & 2f 68 & 32 & $(S)$ \\
\hline 14 & 1k & $\mathrm{CBz}$ & $-\left(\mathrm{CH}_{2}\right)_{4-}$ & $(S, R, R)-L_{11}$ & $2 \mathbf{k}>95$ & 40 & - \\
\hline 15 & $1 k$ & $\mathrm{CBz}$ & $-\left(\mathrm{CH}_{2}\right)_{4-}$ & $(R, S, S)-\mathbf{L}_{14}$ & $\mathbf{2 k}>95$ & 16 & - \\
\hline 16 & $\mathbf{1 j}$ & $\mathbf{C B z}$ & Me & $(S, R, R)-L_{11}$ & $2 \mathbf{j} 0$ & - & -- \\
\hline $17^{\mathrm{d}}$ & $\mathbf{1 i}$ & CONHPh & $\mathbf{P h}$ & $(S, R, R)-\mathbf{L}_{1}$ & $2 \mathbf{i}>95$ & 30 & - \\
\hline 18 & $\mathbf{1 i}$ & CONHPh & $\mathbf{P h}$ & $(R, S, S)-\mathrm{L}_{14}$ & $2 \mathbf{i}>95$ & 29 & - \\
\hline 19 & $1 \mathbf{i}$ & CONHPh & $\mathbf{P h}$ & $(R, S, S)-\mathbf{L}_{12}$ & $2 \mathbf{i}>95$ & 1 & - \\
\hline 20 & 1n & CONHPh & Me & $(R, S, S)-\mathbf{L}_{14}$ & 2n 64 & 16 & - \\
\hline
\end{tabular}

Finally, phosphoramidite ligand $\mathbf{L}_{\mathbf{1 4}}$ bearing benzhydryl substituents afforded $\mathbf{2} \mathbf{f}$ in good to high conversions (68$95 \%)$ along with low to average ee (2-32\%), configuration $(R, S, S)$ being the best (entries 11-13). Otherwise, modifications of the reagent substituents at the $\mathrm{C} 2$ position of the alkenyl chain lead to critical changes of the 
product enantiomeric excess. By offering a $40 \%$ ee of $\mathbf{2 k}$ in a $95 \%$ conversion, reagent $\mathbf{1} \mathbf{k}$ bearing a cyclohexyl group was reactive and quite selective when ligand $(\boldsymbol{S}, \boldsymbol{R}, \boldsymbol{R})-\mathbf{L}_{11}$ was used (entry 14). The ligand $(\boldsymbol{R}, \boldsymbol{S}, \boldsymbol{S})-\mathbf{L}_{14}$ led also to $\mathbf{2 k}$ in high conversion though a much lowered enantiomeric excess was reached (entry 15 ). This result outlined the importance of a match pair [28] between selected $N$-alkenyl reagents and catalysts to reach high ee. Moreover, the steric hindrance at the $\mathrm{C} 2$ position of the substrate appeared also to be the key factor to control in order to avoid any Thorpe-Ingold effect [29] which significantly lowered the conversion or even prevented the reaction (see entries $4,14,16)$. The $N$-alkenyl urea substrate $\mathbf{1 i}$ led to good conversions (95\%) and average enantiomeric excesses (29-30\%) when ligands $(\boldsymbol{S}, \boldsymbol{R}, \boldsymbol{R})-\mathbf{L}_{1}$ and $(\boldsymbol{R}, \boldsymbol{S}, \boldsymbol{S})$-L14 were used (entries 17, 18). However, the use of ligand $(\boldsymbol{R}, \boldsymbol{S}, \boldsymbol{S})-\mathbf{L}_{\mathbf{1 2}}$ resulted in a complete loss of enantioselectivity for $\mathbf{2} \mathbf{i}$ (entry 19). Hence, no improvement of the asymmetric induction could be reached on substrate $\mathbf{1 i}$ using all the prepared substituted phosphoramidites. Finally, $N$-alkenyl urea reagent 1 n bearing methyl substitutents at the $\mathrm{C} 2$ position afforded average yield and lower ee when ligand $(\boldsymbol{R}, \boldsymbol{S}, \boldsymbol{S})$-L14 was used (entry 20). By comparison to binuclear gold(I) catalysts, mononuclear gold(I) catalysts appeared slightly less active and selective for $N$-alkenyl urea substrates. [8e]

\section{Conclusion.}

The gold catalyzed asymmetric intramolecular hydroamination of alkenes was studied screening a series of mononuclear gold (I) and (III) complexes in combination with silver salts. Among the various chiral monophosphine and diaminocarbene ligands tried, the best catalysts arose from mononuclear gold(I) complexes built on BINOL based phosphoramidite ligands. The latest were improved by addition of bulky substituents at the specific 3,3'-positions of the BINOL scaffold. The resulting gold (I) complexes were combined with selected silver salts to afford efficient catalysts for intramolecular hydroamination of alkenes at mild temperatures, with good conversions and average enantioselectivities. Hence, such phosphoramidite based mononuclear gold(I) catalysts appeared as valuable alternatives to binuclear gold(I) catalysts for the hydroamination of alkenes.

\section{Experimental}

\subsection{General remarks.}

All solvents were dried using standard methods and stored over molecular sieves (4 A). Karl-Fischer titrations were performed to guarantee a water content below $5 \mathrm{ppm}$. All silver salts were weighted in a glovebox. All reactions were carried out under a dry nitrogen atmosphere and were repeated at least twice. Analytical thin layer 
chromatography (TLC) was performed on Merck pre-coated $0.20 \mathrm{~mm}$ silica gel Alugram Sil $60 \mathrm{G} / \mathrm{UV}_{254}$ plates. Flash chromatography was carried out with Macherey silica gel (Kielselgel 60). ${ }^{1} \mathrm{H}(300 \mathrm{MHz}),{ }^{13} \mathrm{C}(75 \mathrm{MHz})$ and ${ }^{31} \mathrm{P}(121 \mathrm{MHz})$ spectra were acquired on a Bruker Avance spectrometer. Chemical shifts $(\delta)$ are reported downfield of $\mathrm{Me}_{4} \mathrm{Si}$ in ppm and coupling constants are expressed in Hz. 1,3,5-trimethoxybenzene and 1,2,4,5tetrachlorobenzene were used as internal standards when needed. Infrared spectra were recorded on a ThermoScientific-Nicolet 6700 spectrometer; the samples being prepared with $\mathrm{KBr}$ powder. HPLC was performed on an equipement Hitachi LaChromElite with a micropump, a Peltier oven and a DAD detector. HRMS-ESI analyses were performed at CUMA-Pharm. Dept.-University Lille Nord de-France. Elemental analyses were performed at UCCS, University Lille Nord de France. AuS(Me $)_{2} \mathrm{Cl}$ was prepared following related procedures. [30] BARF and TRIP silver salts were prepared as reported. [31,32] Gold diaminocarbene complexes 3-6 were prepared according to reported procedures. [23,25] See supporting informations for other details.

\subsection{General procedures.}

General Procedure (Ligand screening). In a glovebox, $\mathrm{AuS}(\mathrm{Me})_{2} \mathrm{Cl}(0.01 \mathrm{mmol}, 2.95 \mathrm{mg})$ and the corresponding ligand $(0.01 \mathrm{mmol})$ are disposed in a first Schlenk flask. Dry dichloromethane $(1 \mathrm{~mL})$ is added under a nitrogen atmosphere and the resulting mixture is stirred at room temperature for 2 hours. Afterwards, the solvent is evaporated under vacuum and the resulting solid is dried 30 minutes before addition of AgOTf $(0.009$ $\mathrm{mmol}, 2.31 \mathrm{mg})$ in a glovebox. Dry tetrachloroethane $(1 \mathrm{~mL})$ is added under nitrogen and the resulting solution is stirred for 30 minutes before being transferred to a second Schlenk containing amino-alkene substrate $\mathbf{1 f}(0.18$ $\mathrm{mmol}, 66.9 \mathrm{mg}$ ). After 20 hours of stirring at $30{ }^{\circ} \mathrm{C}$, the solution is filtered through a pad of silica gel using dichloromethane as solvent. After evaporation of solvent under vacuum, the resulting oil is analyzed by ${ }^{1} \mathrm{H}$ NMR and HPLC.

General procedure (Silver salt screening). In a glovebox, $\mathrm{AuS}(\mathrm{Me})_{2} \mathrm{Cl}(0.01 \mathrm{mmol}, 2.95 \mathrm{mg})$ and $(\boldsymbol{R}, \boldsymbol{S}, \boldsymbol{S})-\mathbf{L}_{\mathbf{1}}$ $(0.01 \mathrm{mmol}, 5.40 \mathrm{mg})$ are disposed in a first Schlenk flask. Dry dichloromethane $(1 \mathrm{~mL})$ is then added under a nitrogen atmosphere and the resulting mixture is stirred for two hours at room temperature. Afterwards, the solvent is evaporated under vacuum and the resulting solid is dried 30 minutes before addition of the corresponding silver salt reagent $\mathrm{AgX}(0.009 \mathrm{mmol})$ in a glovebox. Dry toluene $(1 \mathrm{~mL})$ is added under nitrogen atmosphere and the resulting solution is stirred for 30 minutes before being transferred in a second Schlenk flask 
containing amino-alkene substrate $\mathbf{1 f}(0.18 \mathrm{mmol}, 66.9 \mathrm{mg})$. After 20 hours under stirring at $50{ }^{\circ} \mathrm{C}$, the solution is filtered through a pad of silica gel using dichloromethane as solvent. After evaporation of solvents under vacuum, the resulting oil is analyzed by ${ }^{1} \mathrm{H}$ NMR and HPLC.

General procedure (Solvent screening). In a glovebox, $\mathrm{AuS}(\mathrm{Me})_{2} \mathrm{Cl}(0.01 \mathrm{mmol}, 2.95 \mathrm{mg})$ and $(\boldsymbol{R}, \boldsymbol{S}, \boldsymbol{S})-\mathbf{L}_{1}$ $(0.01 \mathrm{mmol}, 5.40 \mathrm{mg})$ were added to a Schlenk flask. Dry dichloromethane $(1 \mathrm{~mL})$ is then added under a nitrogen atmosphere and the resulting mixture is stirred for two hours at room temperature. Afterwards, the solvent is evaporated under vacuum and the resulting solid is dried 30 minutes before addition of AgOTf (0.009 mmol, $2.31 \mathrm{mg})$ in a glovebox. The corresponding dry solvent $(1 \mathrm{~mL})$ is added under a nitrogen atmosphere and the resulting solution is stirred for 30 minutes before being transferred in a second Schlenk flask containing amino-alkene substrate $1 \mathbf{f}(0.18 \mathrm{mmol}, 66.9 \mathrm{mg})$. After 20 hours under stirring at 30 or $50{ }^{\circ} \mathrm{C}$, the solution is filtered through a pad of silica gel using dichloromethane as solvent. After evaporation of solvents under vacuum, the resulting oil is analyzed by ${ }^{1} \mathrm{H}$ NMR and HPLC.

\subsection{Physical and spectra data for compounds.}

\section{Benzyl (5-methyl-2,2-diphenylhex-4-en-1-yl)carbamate $1 \mathrm{~g}$}

The corresponding primary amine was prepared according reported procedures. [33] That reagent (10 mmol, $2.51 \mathrm{~g})$ was then allowed to react with benzylchloroformate $(12 \mathrm{mmol}, 2.05 \mathrm{~g}, 1.71 \mathrm{ml})$ in an ethanol / water (3:2) mixture $(50 \mathrm{~mL})$ at room temperature for 12 hours. The resulting mixture was extracted with diethylether and the organic phases washed with brine. After drying over $\mathrm{MgSO}_{4}$, the solvents were evaporated to lead to an oily residue which was further purified by flash chromatography on silica gel using a 4:1 mixture of petroleum ether and ethylacetate $(\mathrm{Rf}=0.45)$. Compound was recovered as a colorless oil which crystallized slowly to afford a white solid (1.65 g, $4.3 \mathrm{mmol}, 43 \%$ yield). ${ }^{1} \mathrm{H}$ NMR (300 MHz, $\left.\mathrm{CDCl}_{3}\right): \delta=1.38$ (s, 3H), 1.60 (s, 3H), $2.81(\mathrm{~d}$, $J=7.1 \mathrm{~Hz}, 2 \mathrm{H}), 3.93(\mathrm{~d}, J=6.0 \mathrm{~Hz}, 2 \mathrm{H}), 4.39(\mathrm{~m}, 1 \mathrm{H}), 4.91(\mathrm{~m}, 1 \mathrm{H}), 5.05(\mathrm{~s}, 2 \mathrm{H}), 7.30(\mathrm{~m}, 6 \mathrm{H}), 7.60(\mathrm{~m}, 9 \mathrm{H})$. ${ }^{13} \mathrm{C}$ NMR $\left(75 \mathrm{MHz}, \mathrm{CDCl}_{3}\right): \delta=17.7\left(\mathrm{CH}_{3}\right), 26.0\left(\mathrm{CH}_{3}\right), 35.8\left(\mathrm{CH}_{2}\right), 47.9\left(\mathrm{CH}_{2}\right), 50.7(\mathrm{C}), 66.7\left(\mathrm{CH}_{2}\right), 119.1$ $(\mathrm{CH}), 126.4(\mathrm{CH}), 128.1(\mathrm{CH}), 128.2(\mathrm{CH}), 128.5(\mathrm{CH}), 134.9(\mathrm{C}), 136.5(\mathrm{C}), 145.5(\mathrm{C}), 156.3(\mathrm{CO}) . \mathrm{HMRS}$ (ESI) $\mathrm{m} / \mathrm{z}$ calcd for $\mathrm{C}_{27} \mathrm{H}_{29} \mathrm{NO}_{2} \mathrm{Na}: 422.20910[\mathrm{MH}+]$, found : 422.20835. IR (neat, $\mathrm{cm}^{-1}$ ): 3291, 1706, 1497 , $1403,1364,1069,1034,976,749,695$. 


\section{Benzyl (2,2-diphenylhex-4-en-1-yl)carbamate 1h}

The corresponding primary amine was prepared according reported procedures.[34] That reagent (10 mmol, 2.65 g) was then allowed to react with benzylchloroformate $(12 \mathrm{mmol}, 2.05 \mathrm{~g}, 1.71 \mathrm{ml})$ in an ethanol / water (3:2) mixture $(50 \mathrm{~mL})$ at room temperature for 12 hours. The resulting mixture was extracted with diethylether and the organic phases washed with brine. After drying over $\mathrm{MgSO}_{4}$, the solvents were evaporated to lead to an oily residue which was further purified by flash chromatography on silica gel using a 4:1 mixture of petroleum ether and ethylacetate $(\mathrm{Rf}=0.55)$. Compound was recovered as a colorless oil which crystallized slowly to afford a white solid (1.84 g, $4.6 \mathrm{mmol}, 45 \%$ yield). ${ }^{1} \mathrm{H}$ NMR $\left(300 \mathrm{MHz}, \mathrm{CDCl}_{3}\right.$, ratio of trans / cis isomers $\left.(4: 1)\right): \delta=$ $1.25(\mathrm{~d}, J=6.2 \mathrm{~Hz}, 3 \mathrm{H})(\mathrm{cis}), 1.46(\mathrm{~d}, J=6.3 \mathrm{~Hz}, 3 \mathrm{H})(\operatorname{trans}), 2.70(\mathrm{~d}, J=7.7 \mathrm{~Hz}, 2 \mathrm{H})(\operatorname{trans}), 2.78(\mathrm{~d}, J=7.3 \mathrm{~Hz}$ $2 \mathrm{H})(\mathrm{cis}), 3.83(\mathrm{~m}, 2 \mathrm{H}), 4.12(\mathrm{~m}, 1 \mathrm{H})(\mathrm{cis}), 4.26(\mathrm{~m}, 1 \mathrm{H})(\operatorname{trans}), 4.96(\mathrm{~s}, 3 \mathrm{H}), 5.28(\mathrm{~m}, 1 \mathrm{H})(\operatorname{trans}), 5.41(\mathrm{~m}, 1 \mathrm{H})$ (cis), $6.95(\mathrm{~m}, 6 \mathrm{H}), 7.17(\mathrm{~m}, 9 \mathrm{H}) .{ }^{13} \mathrm{C} \mathrm{NMR}\left(75 \mathrm{MHz}, \mathrm{CDCl}_{3}\right): \delta=12.8\left(\mathrm{CH}_{3}, \mathrm{cis}\right), 18.0\left(\mathrm{CH}_{3}, \operatorname{trans}\right), 34.4\left(\mathrm{CH}_{2}\right.$, cis), $40.7\left(\mathrm{CH}_{2}\right.$, trans), $47.7\left(\mathrm{CH}_{2}\right.$, trans $), 48.0\left(\mathrm{CH}_{2}\right.$, cis $), 50.4(\mathrm{C}$, trans+cis $), 66.7\left(\mathrm{CH}_{2}\right.$, trans+cis $), 125.3(\mathrm{CH}$, cis), $125.9(\mathrm{CH}$, trans), $126.5(\mathrm{CH}$, trans $), 126.6(\mathrm{CH}$, cis $), 127.3(\mathrm{CH}, \mathrm{cis}), 128.1(\mathrm{CH}), 128.2(\mathrm{CH}), 128.3(\mathrm{CH})$, $128.4(\mathrm{CH}), 128.5(\mathrm{CH}), 128.6(\mathrm{CH}), 129.4(\mathrm{CH}$, trans $), 136.5(\mathrm{C}$, cis $), 136.6(\mathrm{C}$, trans $), 145.3(\mathrm{C}$, cis $), 145.4(\mathrm{C}$, trans), 156.2 (CO, trans), 156.3 (CO, cis). HMRS (ESI) m/z calcd for $\mathrm{C}_{26} \mathrm{H}_{28} \mathrm{NO}_{2}: 386.21146$ [MH+], found : 386.02192. IR (neat, $\left.\mathrm{cm}^{-1}\right): 3433,1706,1495,1445,1362,1217,1051,968,776,700$.

\section{Benzyl 2-methyl-4,4-diphenylpyrrolidine-1-carboxylate $2 \mathrm{f}[8 \mathrm{v}]$}

Isolated after flash chromatography with petroleum ether/EtOAc $(9: 1), \mathrm{Rf}=0.5$, as a colorless oil. ${ }^{1} \mathrm{H}$ NMR $(300$ $\mathrm{MHz}, \mathrm{CDCl}_{3}$, ratio of rotamers $\left.(1: 1)\right): \delta=[1.29(d, J=6.0 \mathrm{~Hz}), 1.36(d, J=6 \mathrm{~Hz}),(1: 1), 3 \mathrm{H}],[2.26(d d, J=9.6$ $\mathrm{Hz}$ and $J=12.8 \mathrm{~Hz}), 2.31(d d, J=9.6 \mathrm{~Hz}$ and $12.4 \mathrm{~Hz}),(1: 1), 1 \mathrm{H}], 2.80-2.86(m, \mathrm{H}), 3.65-3.81(m, 2 \mathrm{H}),[4.58$ $(d d, J=1.6 \mathrm{~Hz}$ and $J=11.6 \mathrm{~Hz}), 4.74(d d, J=2.0 \mathrm{~Hz}$ and $J=11.6 \mathrm{~Hz}),(1: 1), 1 \mathrm{H}],[5.18(d, J=12.4 \mathrm{~Hz}),(1: 1)$, $1 \mathrm{H}],[5.09(d, J=12.4 \mathrm{~Hz}), 5.31(d, J=12.4 \mathrm{~Hz}),(1: 1), 1 \mathrm{H}], 7.11-7.40(m, 15 \mathrm{H}) .{ }^{13} \mathrm{C} \mathrm{NMR}\left(75 \mathrm{MHz}, \mathrm{CDCl}_{3}\right.$, ratio of rotamers $(1: 1)): \delta=\left[20.4,21.5,(1: 1), \mathrm{CH}_{3}\right],\left[46.3,47.2,(1: 1), \mathrm{CH}_{2}\right],[52.5,52.9,(1: 1), \mathrm{C}],[53.1,53.1$, (1:1), $\mathrm{CH}], 56.2\left(\mathrm{CH}_{2}\right),\left[66.9,67.1,(1: 1), \mathrm{CH}_{2}\right], 126.6(\mathrm{CH}), 126.7(\mathrm{CH}), 126.7(\mathrm{CH}), 126.8(\mathrm{CH}), 126.8(\mathrm{CH})$, $127.1(\mathrm{CH}), 127.8(\mathrm{CH}), 128.1(\mathrm{CH}), 128.3(\mathrm{CH}), 128.3(\mathrm{CH}), 128.7(\mathrm{CH}), 128.8(\mathrm{CH}), 128.8(\mathrm{CH}), 128.8(\mathrm{CH})$, $[137.3,137.4,(1: 1), \mathrm{C}],[145.3,145.5,(1: 1), \mathrm{C}],[146.0,146.0,(1: 1), \mathrm{C}],[154.9,155.7,(1: 1), \mathrm{CO}] .[\alpha]_{\mathrm{D}}{ }^{20}=+35$ $\left(\mathrm{CH}_{2} \mathrm{Cl}_{2}, c 0.67 \mathrm{~g} / 100 \mathrm{~mL}\right.$, at $28 \%$ ee $)$. Enantiopurity was determined by HPLC using Daicel Chiralpak ${ }^{\mathrm{TM}}$ IA column (at $25^{\circ} \mathrm{C}$ ) with $(90 / 10) n$-hexane/iPrOH, $1.0 \mathrm{~mL} / \mathrm{min}, \lambda=200 \mathrm{~nm}$. 


\section{2-Methyl-4,4-diphenyl-pyrrolidine-1-carboxylic acid phenylamide $2 \mathrm{i}[8 \mathrm{u}, 8 \mathrm{w}]$}

Isolated after flash chromatography with petroleum ether/EtOAc $(8: 2), \mathrm{Rf}=0.37$, as yellow solid.

${ }^{1} \mathrm{H}$ NMR $\left(300 \mathrm{MHz}, \mathrm{CDCl}_{3}\right): \delta=7.44(\mathrm{~d}, J=7.7 \mathrm{~Hz}, 2 \mathrm{H}), 7,13-7.30(\mathrm{~m}, 12 \mathrm{H}), 7.01(\mathrm{tt}, J=1.2,7.3 \mathrm{~Hz}, 1 \mathrm{H})$, 6.54 (br s, $1 \mathrm{H}), 4.60(\mathrm{~d}, J=10.6 \mathrm{~Hz}, 1 \mathrm{H}), 3.79-3.87(\mathrm{~m}, 1 \mathrm{H}), 3.75(\mathrm{~d}, J=10.8 \mathrm{~Hz}, 1 \mathrm{H}), 2.84(\mathrm{ddd}, J=1.4,6.3$, $12.3 \mathrm{~Hz}, 1 \mathrm{H}), 2.35(\mathrm{dd}, J=9.2,12.3 \mathrm{~Hz}, 1 \mathrm{H}), 1.34(\mathrm{~d}, 3 \mathrm{H}) .{ }^{13} \mathrm{C} \mathrm{NMR}\left(75 \mathrm{MHz}, \mathrm{CDCl}_{3}\right): \delta=154.2,145.6$, $145.2,139.2,128.9,128.7,128.5,126.8,126.6,126.4,122.9,119.8,56.2,52.8,52.1,46.6,20.8 .[\alpha]_{\mathrm{D}}^{20}=+30$ $\left(\mathrm{CH}_{2} \mathrm{Cl}_{2}, c 0.26 \mathrm{~g} / 100 \mathrm{~mL}\right.$, at $29 \%$ ee). Enantiopurity was determined by HPLC using Daicel Chiralpak ${ }^{\mathrm{TM}}$ IA $\mathrm{CSP}\left(\right.$ at $25^{\circ} \mathrm{C}$ ) with $(90 / 10) n$-hexane $/ \mathrm{PrOH}, 1.0 \mathrm{~mL} / \mathrm{min}, \lambda=200 \mathrm{~nm}$.

\section{Benzyl 3-methyl-2-azaspiro[4.5]decane-2-carboxylate 2k [8v]}

Isolated after flash chromatography with petroleum ether/EtOAc $(9: 1), \mathrm{Rf}=0.5$, as a colorless oil. ${ }^{1} \mathrm{H}$ NMR $(300$ $\mathrm{MHz}, \mathrm{CDCl}_{3}$, ratio of rotamers (1:1)): $\delta=1.31(\mathrm{~m}, 14 \mathrm{H}), 2.02(\mathrm{ddd}, J=1.2,7.5,12.9 \mathrm{~Hz}, 1 \mathrm{H}), 3.00(\mathrm{~d}, J=10.8$ $\mathrm{Hz}, 1 \mathrm{H}), 3.59(\mathrm{bs}, 1 \mathrm{H}), 3.90(\mathrm{~m}, 1 \mathrm{H}), 5.11(\mathrm{~m}, 2 \mathrm{H}), 7.29(\mathrm{~m}, 5 \mathrm{H}) .{ }^{13} \mathrm{C} \mathrm{NMR}\left(75 \mathrm{MHz}, \mathrm{CDCl}_{3}\right.$, ratio of rotamers (3:2)): $\delta=20.7$ (major), 21.8 (minor), 22.9 (major), 23.8 (minor), 26.1, 34.7, 36.6, 40.9 (minor), 41.2 (major), 45.5 (major), 46.4 (minor), 51.9 (minor), 52.6 (major), 56.7, 66.3 (major), 66.6 (minor), 127.6, 127.7, 128.3, 137.1 (minor), 137.2 (major), 154.9 (major), 155.3 (minor). $[\alpha]_{\mathrm{D}}{ }^{20}=+17\left(\mathrm{CH}_{2} \mathrm{Cl}_{2}, c 0.144 \mathrm{~g} / 100 \mathrm{~mL}\right.$, at $40 \%$ ee). Enantiopurity was determined by HPLC using Regis Whelk01 ${ }^{\mathrm{TM}}$ CSP (at $25^{\circ} \mathrm{C}$ ) with (98/02) $n$ hexane/iPrOH, $1.0 \mathrm{~mL} / \mathrm{min}, \lambda=200 \mathrm{~nm}$.

\section{2-Methyl-4,4-dimethyl-pyrrolidine-1-carboxylic acid phenylamide 2n}

Isolated after flash chromatography with petroleum ether/EtOAc $(8: 2), \mathrm{Rf}=0.25$, as a pale yellow solid. ${ }^{1} \mathrm{H} \operatorname{NMR}\left(300 \mathrm{MHz}, \mathrm{CDCl}_{3}\right): \delta=7.39(\mathrm{~d} ; J=7.5 \mathrm{~Hz}, 2 \mathrm{H}), 7.27(\mathrm{t}, J=7.4 \mathrm{~Hz}, 2 \mathrm{H}), 7.00(\mathrm{t}, J=7.7 \mathrm{~Hz}, 1 \mathrm{H})$, $6.15(\mathrm{bs}, 1 \mathrm{H}), 4.07(\mathrm{~m}, 1 \mathrm{H}), 3.30(\mathrm{~d}, J=9.3 \mathrm{~Hz}, 1 \mathrm{H}), 3.17(\mathrm{~d}, J=9.3 \mathrm{~Hz}, 1 \mathrm{H}), 1.96(\mathrm{dd}, J=7.1,5.4 \mathrm{~Hz}, 1 \mathrm{H})$, $1.42(\mathrm{dd}, J=8.9,3.9 \mathrm{~Hz}, 1 \mathrm{H}), 1.35(\mathrm{~s}, 3 \mathrm{H}), 1.33(\mathrm{~s}, 3 \mathrm{H}), 1.13(\mathrm{~s}, 3 \mathrm{H}), 1.04(\mathrm{~s}, 3 \mathrm{H}) .{ }^{13} \mathrm{C} \mathrm{NMR}\left(75 \mathrm{MHz}, \mathrm{CDCl}_{3}\right)$ : $\delta=21.3,26.5,26.8,37.8,48.4,53.1,59.6,119.5,122.8,128.9,139.3,154.4$. HMRS (ESI) m/z calcd for $\mathrm{C}_{14} \mathrm{H}_{21} \mathrm{~N}_{2} \mathrm{O}: 233.16484[\mathrm{MH}+]$, found : 233.16367. IR (neat, $\mathrm{cm}^{-1}$ ): 3266, 2363, 1641, 1530, 1443, 1371, 1059, 1029, 750, 692. $[\alpha]_{\mathrm{D}}{ }^{20}=-6\left(\mathrm{CH}_{2} \mathrm{Cl}_{2}, c 0.116 \mathrm{~g} / 100 \mathrm{~mL}\right.$, at $12 \%$ ee $)$. Enantiopurity was determined by HPLC using Daicel Chiralpak ${ }^{\mathrm{TM}} \mathrm{IA}$ CSP (at $25^{\circ} \mathrm{C}$ ) with (90/10) $n$-hexane/iPrOH, $1.0 \mathrm{~mL} / \mathrm{min}, \lambda=200 \mathrm{~nm}$. 


\section{Acknowledgements}

This work is first financed by the French National Research Agency with project ANR-09-BLAN-0032-02 (with a PhD fellowship to F.M). The French "Ministère de la Recherche et des Nouvelles Technologies" is gratefully acknowledged for a PhD fellowship to M.A.A. Support from CNRS is warmly acknowledged. Partial funding from Région Nord-Pas de Calais with "Projet Prim: Etat-Région" and "Fonds Européen de Développement Régional (FEDER)" is also appreciated. Mrs C. Méliet (UCCS) is thanked for elemental analyses on organic samples. Mrs C. Delabre (UCCS) is thanked for assistance with GC and HPLC analyses. Mrs N. Duhal (CUMA, Université Lille 2) is thanked for HRMS analyses. The authors are grateful to the reviewers for their helpful comments and advices.

\section{References:}

[1] (a) J. J. Brunet, D. Neibecker, In Catalytic Heterofunctionalization from Hydroamination to Hydrozirconation, (Eds.: Togni, A.; Grutzmacher, H.), Wiley-VCH: Weinheim, Germany, 2001, pp. 10-20. (b) S. Doye, In Science of Synthesis, Vol. 40a, (Eds.: Enders, D.; Schaumann, E.), Thieme: Stuttgart, 2009, pp. 241304. (c) J. Hannedouche, E. Schulz, Chem. Eur. J. 19 (2013) 4972-4985. (d) P. A. Dub, R. Poli, J. Am. Chem. Soc. 132 (2010) 13799-13812. (e) U. M. Dzhemilev, G. A. Tolstikov, R. I. Khusnutdinov, Russ. J. Org. Chem. 45 (2009) 957-987. (f) S. R. Chemler Org. Biomol. Chem. 7 (2009) 3009-3019. (g) T. E. Mueller, K. C. Hultzsch, M. Yus, F. Foubelo, M. Tada, Chem. Rev. 108 (2008) 3795-3892. (h) I. Aillaud, J. Collin, J. Hannedouche, E. Schulz, Dalton Trans. (2007) 5105-5118. (i) K. C. Hultzsch, Adv. Synth. Catal. 347 (2005) 367-391. (j) A. L. Odom, Dalton Trans. (2005) 225-233. (k) I. Bytschkov, S. Doye, Eur. J. Org. Chem. (2003) 935-946. (1) P. W. Roesky, T. E. Müller, Angew. Chem. Int. Ed. 42 (2003) 2708-2710. (m) T. E. Müller, M. Beller, Chem. Rev. 98 (1998) 675-703.

[2] For examples of asymmetric intramolecular hydroaminations with lanthanide complexes, see: (a) M. A. Giardello, V. P. Conticello, L. Brard, M. R. Gagne, T. J. Marks, J. Am. Chem. Soc. 116 (1994) 10241-10254. (b) S. Hong, S. Tian, M. V. Metz, T. J. Marks, J. Am. Chem. Soc. 125 (2003) 14768-14783. (c) J. Y. Kim, T. Livinghouse, Org. Lett. 7 (2005) 1737-1739. (d) J. Collin, J. Daran, O. Jacquet, E. Schulz, A. Trifonov, Chem. Eur. J. 11 (2005) 3455-3462. (e) D. Riegert, J. Collin, A. Meddour, E. Schulz, A. Trifonov, J. Org. Chem. 71 (2006) 2514-2517. (f) D. V. Gribkov, K. C. Hultzsch, F. Hampel, J. Am. Chem. Soc. 128 (2006) 3748-3759. (g) Y. Chapurina, J. Hannedouche, J. Collin, R. Guillot, E. Schulz, A. Trifonov, Chem. Commun. 46 (2010) 69186920. (h) A. L. Reznichenko, H. P. Nguyen, K. C. Hultzsch, Angew. Chem. Int. Ed. 49 (2010) 8984-8987. (i) Y. 
Chapurina, H. Ibrahim, R. Guillot, E. Kolodziej, J. Collin, A. Trifonov, E. Schulz, J. Hannedouche, J. Org. Chem. 76 (2011) 10163-10172. (j) K. Manna, M. L. Kruse, A. D. Sadow, ACS Catal. 1 (2011) 1637-1642. (k) P. Benndorf, J. Jenter, L. Zielke, P. W. Roesky, Chem. Commun. 47 (2011) 2574-2576. (l) Y. Zhang, W. Yao, H. Li, Y. Mu, Organometallics 31 (2012) 4670-4679. (m) A. L. Reznichenko, K. C. Hultzsch, Organometallics 32 (2013) 1394-1408.

[3] For examples of asymmetric intramolecular hydroamination with group 4 complexes, see: (a) D. V. Gribkov, K. C. Hultzsch, Angew. Chem. Int. Ed. 43 (2004) 5542-5546. (b) P. D. Knight, I. Munslow, P. N. O’Shaughnessy, P. Scott, Chem. Commun. (2004) 894-895. (c) J. A. Bexrud, J. D. Beard, D. C. Leitch, L. L. Schafer, Org. Lett. 7 (2005) 1959-1962; (d) H. Kim, P. H. Lee, T. Livinghouse, Chem. Commun. (2005) 52055206; (e) C. Müller, C. Loos, N. Schulenberg, S. Doye, Eur. J. Org. Chem. (2006) 2499-2503. (f) D. A. Watson, M. Chiu, R. G. Bergman, Organometallics 25 (2006) 4731-4733. (g) M. C. Wood, D. C. Leitch, C. S. Yeung, J. A. Kozak, L. L. Schafer, Angew. Chem., Int. Ed. 46 (2007) 354-358. (h) A. L. Gott, A. J. Clarke, G. J. Clarkson, P. Scott, Organometallics 26 (2007) 1729-1737. (i) A. L. Gott, A. J. Clarke, G. J. Clarkson, P. Scott, Chem. Commun. (2008) 1422-1424. (j) G. Zi, X. Liu, L. Xiang, H. Song, Organometallics 28 (2009) 1127-1137. (k) G. Zi, F. Zhang, L. Xiang, Y. Chen, W. Fang, H. Song, Dalton Trans. 39 (2010) 4048-4061. (1) A. L. Reznichenko, K. C. Hultzsch, Organometallics 29 (2010) 24-27. (m) K. Manna, S. Xu, A. D. Sadow, Angew. Chem., Int. Ed. 50 (2011) 1865-1868. (n) K. Manna, W. C. Everett, G. Schoendorff, A. Ellern, T. L. Windus, A. D. Sadow, J. Am. Chem. Soc. 135 (2013) 7235-7250.

[4] For examples of asymmetric intramolecular hydroamination with main-group metals, see: (a) M. R. Crimmin, I. J. Casely, M. S. Hill, J. Am. Chem. Soc. 127 (2005) 2042-2043. (b) P. H. Martinez, K. C. Hultzsch, F. Hampel, Chem. Commun. (2006) 2221-2223. (c) T. Ogata, A. Ujihara, S. Tsuchida, T. Shimizu, A. Kaneshige, K. Tomioka, Tetrahedron Lett. 48 (2007) 6648-6650. (d) S. Datta, P. W. Roesky, S. Blechert, Organometallics 26 (2007) 4392-4394. (e) F. Buch, S. Z. Harder, Naturforsch. 63b (2008) 169-177. (f) S. Datta, M. T. Gamer, P. W. Roesky, Organometallics 27 (2008) 1207-1213; (g) A. G. M. Barrett, M. R. Crimmin, M. S. Hill, P. B. Hitchcock, C. Kociok-Köhn, P. A. Procopiou, Inorg. Chem. 47 (2008) 7366-7376; (h) M. Arrowsmith, M. S. Hill, G. Kociok-Köhn, Organometallics 28 (2009) 1730-1738. (i) P. Horrillo-Martínez, K. C. Hultzsch, Tetrahedron Lett. 50 (2009) 2054-2056. (j) M. R. Crimmin, M. Arrowsmith, A. G. M. Barrett, I. J. Casely, M. S. Hill, P. A. Procopiou, J. Am. Chem. Soc. 131 (2009) 9670-9685. (k) X. Zhang, T. J. Emge, K. C. Hultzsch, Organometallics 29 (2010) 5871-5877. (1) J. Deschamp, C. Olier, E. Schulz, R. Guillot, J. Hannedouche, J. Collin, Adv. Synth. Catal. 352 (2010) 2171-2176. (m) J. Deschamp, J. Collin, J. Hannedouche, 
E. Schulz, Eur. J. Org.Chem. (2011) 3329-3338. (n) J. S. Wixey, B. D. Ward, Chem. Commun. 47 (2011) 54495451. (o) J. S. Wixey, B. D. Ward, Dalton Trans. 40 (2011) 7693-7696. (p) J. Jenter, R. Köppe, P. W. Roesky, Organometallics 30 (2011) 1404-1413. (q) S. R. Neal, A. Ellern, A. D. Sadow, J. Organomet. Chem. 696 (2011) 228-234. (r) X. Zhang, T. J. Emge, K. C. Hultzsch, Angew. Chem., Int. Ed. 51 (2012) 394-398. (s) C. Brinkmann, A. G. M. Barrett, M. S. Hill, P. A. Procopiu, J. Am. Chem. Soc. 134 (2012) 2193-2207. (t) T. D. Nixon, B. D. Ward, Chem. Commun. 48 (2012) 11790-11792.

[5] For examples of asymmetric intramolecular hydroamination with late transition metals, see: (a) L. M. Lutete, I. Kadota, Y. Yamamoto, J. Am. Chem. Soc. 126 (2004) 1622-1623. (b) N. T. Patil, L. M. Lutete, H. Wu, N. K. Pahadi, I. D. Gridnev, Y. Yamamoto, J. Org. Chem. 71 (2006) 4270-4279. (c) X. Shen, S. L. Buchwald, Angew. Chem. Int. Ed. 49 (2010) 564-567. (d) B. W. Turnpenny, K. L. Hyman, S. R. Chemler, Organometallics 31 (2012) 7819-7822. For examples of asymmetric intermolecular hydroaminations with late transition metals, see: (e) R. Dorta, P. Egli, F. Zurcher, A. Togni, J. Am. Chem. Soc. 119 (1997) 10857-10858. (f) L. Fadini, A. Togni, Chem. Commun. (2003) 30-31. (g) J. Zhou, J. F. Hartwig, J. Am. Chem. Soc. 130 (2008) 12220-12221. (h) M. Otsuka, H. Yokoyama, K. Endo, T. Shibata, Org. Biomol. Chem. 10 (2012) 3815-3818. (i) C. S. Sevov, J. Zhou, J. F. Hartwig, J. Am. Chem. Soc. 134 (2012) 11960-11963. (j) Pan, S.; Endo, K.; Shibata, T. Org. Lett. 14 (2012) 780-783.

[6] Reviews on gold catalysis with C-C multiple bond substrates: (a) M. Rudolph, A. S. K. Hashmi, Chem. Commun. 47 (2011) 6536-6544. (b) A. S. K. Hashmi, M. Buehrle, Aldrichimica Acta 43 (2010) 27-33. (c) R. A. Widenhoefer, Chem. Eur. J. 14 (2008) 5382-5391. (d) D. J. Gorin, B. D. Sherry, F. D. Toste, Chem. Rev. 108 (2008) 3351-3378. (e) A. S. K. Hashmi Chem. Rev. 107 (2007) 3180-3211. (f) R. A. Widenhoefer, X. Han, Eur. J. Org. Chem. (2006) 4555-4563.

[7] Examples on gold catalysed hydroamination of alkynes: (a) T. Wang, S. Shi, D. Pflästerer, E. Rettenmeier, M. Rudolph, F. Rominger, A. S. K. Hashmi, Chem. Eur. J. 20 (2014) 292-296. (b) M. Murai, Y. Sota, Y. Onohara, J. Uenishi, M. Uemura, J. Org. Chem. 78 (2013) 10986-10995. (c) M. J. López-Gómez, D. Martin, G. Bertrand, Chem. Commun. 49 (2013) 4483-4485. (d) L.-A. Schaper, X. Wei, S. J. Hock, A. Pöthig, K. Öfele, M. Cokoja, W. A. Herrmann, F. E. Kühn, Organometallics 32 (2013) 3376-3384. (e) A. Duriš, D. M. Barber, H. J. Sanganee, D. J. Dixon, Chem. Commun. 49 (2013) 2777-2779. (f) S. Bouvet, X. Moreau, V. Coeffard, C. Greck, J. Org. Chem. 78 (2013) 427-437. (g) A. Arcadi, E. Pietropaolo, A. Alvino, V. Michelet, Org. Lett. 15 (2013) 2766-2769. (h) S. Gonell, M. Poyatos, E. Peris, Angew. Chem. Int. Ed. 52 (2013) 7009 7013. (i) V. Lavallo, J. H. Wright II, F. S. Tham, S. Quinlivan, Angew. Chem. Int. Ed. 52 (2013) 3172-3176. (j) 
K. H. Nguyen, S. Tomasi, M. Le Roch, L. Toupet, J. Renault, P. Uriac, N. Gouault, J. Org. Chem. 78 (2013) 7809-7815. (k) H. Chiba, Y. Sakai, A. Ohara, S. Oishi, N. Fujii, H. Ohno, Chem. Eur. J. 19 (2013) 8875-8883. (l) S. Fustero, P. Bello, J. Miró, M. Sánchez-Roselló, M. A. Maestro, J. González, C. del Pozo, Chem. Commun. 49 (2013) 1336-1338. (m) Y. P. He, H. Wu, D. F. Chen, J. Yu, L. Z. Gong, Chem. Eur. J. 19 (2013) 5232-5237. (n) X. Chen, H. Chen, X. Ji, H. Jiang, Z. J. Yao, H. Liu, Org. Lett. 15 (2013) 1846-1849. (o) M. Saifuddin, S. Samala, D. G. V. Krishna, B. Kundu, Synthesis 45 (2013) 1553-1563. (p) S. Fustero, I. Ibáñez, P. Barrio, M. A. Maestro, S. Catalán, Org. Lett. 15 (2013) 832-835. (q) A. W. Gregory, P. Jakubec, P. Turner, D. J. Dixon, Org. Lett. 15 (2013) 4330-4333. (r) T. T. H. Trinh, K. H. Nguyen, P. de Aguiar Amaral, N. Gouault, Beilstein J. Org. Chem. 9 (2013) 2042-2047. (s) D. D. Vachhani, V. P. Mehta, S. G. Modha, K. Van Heck, L. Van Meervelt, E. V. Van der Eycken, Adv. Synth. Catal. 354 (2012) 1593-1599. (t) J. A. T. O’Neill, G. M. Rosair, A. L. Lee, Catal. Sci. Technol. 2 (2012) 1818-1821. (u) E. Alvarado, A. C. Badaj, T. G. Larocque, G. G. Lavoie, Chem. Eur. J. 18 (2012) 12112-12121. (v) H. Wu, Y. P. He, L. Z. Gong, Adv. Synth. Catal. 354 (2012) 975-980. (w) N. T. Patil, A. K. Mutyala, A. Konala, R. B. Tella, Chem. Commun. 48 (2012) 3094-3096. (x) S. Li, Z. Li, Y. Yuan, D. Peng, Y. Li, L. Zhang, Y. Wu, Org. Lett. 14 (2012) 1130-1133, (y) H. Chiba, S. Oishi, N. Fujii, H. Ohno, Angew. Chem. Int. Ed. 51 (2012) 9169-9172. (z) M. Katari, M. N. Rao, G. Rajaraman, P. Ghosh, Inorg. Chem. 51 (2012) 5593-5604. (aa) C. Sarcher, A. Lühl, F. C. Falk, S. Lebedkin, M. Kühn, C. Wang, J. Paradies, M. M. Kappes, W. Klopper, P. W. Roesky, Eur. J. Inorg. Chem. (2012) 5033-5042. (ab) D. M. Barber, H. J. Sanganee, D. J. Dixon, Org. Lett. 14 (2012) 5290-5296. (ac) J. Zhu, H. Xie, Z. Chen, S. Li, Y. Wu, Org. Biomol. Chem. 10 (2012) 516-523. (ad) A. K. Mourad, J. Leutzow, C. Czekelius, Angew. Chem. Int. Ed. 51 (2012) 11149-11152. (ae) Y. Suzuki, S. Naoe, S. Oishi, N. Fujii, H. Ohno, Org. Lett. 14 (2012) 326-329. (af) C. Wang, J. Sperry, Synlett 23 (2012) 1824-1828. (ag) G. Kovács, A. Lledós, G. Ujaque, Angew. Chem. Int. Ed. 50 (2011) 1114711151. (ah) A. Simonneau, F. Jaroschik, D. Lesage, M. Karanik, R. Guillot, M. Malacria, J. C. Tabet, J. P. Goddard, L. Fensterbank, V. Gandon, Y. Gimbert, Chem. Sci. 2 (2011) 2417-2422. For reviews: (ai) N. T. Patil, V. Singh, J. Organomet. Chem. 696 (2011) 419-432. (aj) R. Severin, S. Doye, Chem. Soc. Rev. 36 (2007) $1407-$ 1420. (ak) A. S. K. Hashmi, Gold Bull. 36 (2003) 3-9.

[8] Examples of gold catalysed hydroamination of alkenes: (a) Y. W. Sun, Q. Xu, M. Shi, Beilstein J. Org. Chem. 9 (2013) 2224-2232. (b) S. K. Singh, M. Yadav, S. Behrens, P. W. Roesky, Dalton Trans. 42 (2013) 10404-10408. (c) D. H. Zhang, K. Du, M. Shi, Org. Biomol. Chem. 10 (2012) 3763-3766. (d) H. Kitahara, H. Sakurai, Chem. Lett. 41 (2012) 1328-1330. (e) M. Kojima, K. Mikami, Synlett 23 (2012) 57-61. (f) X. Giner, C. 
Nájera, G. Kovács, A. Lledós, G. Ujaque, Adv. Synth. Catal. 353 (2011) 3451-3466. (g) H. Kitahara, H. Sakurai, J. Organomet. Chem. 696 (2011) 442-449. (h) H. Seo, D. R. Snead, K. A. Abboud, S. Hong, Organometallics 30 (2011) 5725-5730. (i) H. Seo, B. P. Roberts, K. A. Abboud, K. M. Merz, S. Hong, Org. Lett. 12 (2010) 48604863. (j) S. Hidehiro, H. Sakurai, Chem. Lett. 39 (2010) 46-48. (k) A. Iglesias, K. Muniz, Chem. Eur. J. 15 (2009) 10563-10569. (1) Z. Zhang, S. D. Lee, R. A. Widenhoefer, J. Am. Chem. Soc. 131 (2009) 5372-5373. (m) M. C. P. Yeh, H. F. Pai, Z. J. Lin, B. R. Lee, Tetrahedron 65 (2009) 4789-4794. (n) C. F. Bender, R. A. Widenhoefer, Chem. Commun. (2008) 2741-2743. (o) X. Giner, C. Nájera, Org. Lett. 10 (2008) 2919-2922. (p) L. Leseurre, P. Y. Toullec, J. P. Genêt, V. Michelet, Org. Lett. 9 (2007) 4049-4052. (q) M. Shi, L. P. Liu, J. Tang, Org. Lett. 8 (2006) 4043-4046. (r) J. Zhang, C. G. Yang, C. G.; He, C. J. Am. Chem. Soc. 128 (2006) 1798-1799. (s) C. Brouwer, C. He, Angew. Chem. Int. Ed. 45 (2006) 1744-1747. (t) X. Y. Liu, C. H. Li, C. M. Che, Org. Lett. 8 (2006) 2707-2710. (u) C. F. Bender, R. A. Widenhoefer, Chem. Commun. (2006) 4143-4144. (v) X. Han, R. A. Widenhoefer, Angew. Chem. Int. Ed. 45 (2006) 1747-1749. (w) C. F. Bender, R. A. Widenhoefer, Org. Lett. 8 (2006) 5303-5305.

[9] Examples of gold catalysed hydroamination of allenes: (a) C. Zhang, S. Q. Zhang, H. J. Cai and D. M. Cui, Beilstein J. Org. Chem. 9 (2013) 1045-1050. (b) D. Pflästerer, P. Dolbundalchok, S. Rafique, M. Rudolph, F. Rominger, A. S. K. Hashmi, Adv. Synth. Catal. 355 (2013) 1383-1393. (c) J. Erdsack, N. Krause, Beilstein J. Org. Chem. 9 (2013) 1936-1942. (d) T. Roth, H. Wadepohl, D. S. Wright, L. H. Gade, Chem. Eur. J. 19 (2013) 13823-13837. (e) M. C. M. Higginbotham, M. W. P. Bebbington, Chem. Commun. 48 (2012) 7565-7567. (f) G. Broggini, E. Borsini, A. Fasana, G. Poli, F. Liron, Eur. J. Org. Chem. (2012) 3617-3624. (g) K. L. Butler, M. Tragni, R. A. Widenhoefer, Angew. Chem. Int. Ed. 51 (2012) 5175-5178. (h) L. I. Rodríguez, T. Roth, J. L. Fillol, H. Wadepohl, L. H. Gade, Chem. Eur. J. 18 (2012) 3721-3728. (i) L. Liu, F. Wang, W. Wang, M. Zhao, M. Shi, Beilstein J. Org. Chem. 7 (2011) 555-564. (j) J. H. Kim, S. W. Park, S. R. Park, S. Y. Lee, E. J. Kang, Chem. Asian J. 6 (2011) 1982-1986. (k) R. Kinjo, B. Donnadieu, G. Bertrand, Angew. Chem. Int. Ed. 50 (2011) 5560-5563. (1) A. S. K. Hashmi, A. M. Schuster, S. Litters, F. Rominger, M. Pernpointner, Chem. Eur. J. 17 (2011) 5661-5667. (m) H. Li, S. D. Lee, R. A. Widenhoefer, J. Organomet. Chem. 696 (2011) 316-320. (n) R. L. LaLonde, Z. J. Wang, M. Mba, A. D. Lackner, F. D. Toste, Angew. Chem. Int. Ed. 49 (2010) 598-601. (o) Z. J. Wang, D. Benitez, E. Tkatchouk, W. A. Goddard III, F. D. Toste, J. Am. Chem. Soc. 132 (2010) 13064-13071. (p) C. Bartolomé, D. García-Cuadrado, Z. Ramiro, P. Espinet, Organometallics 29 (2010) 3589-3592. (q) A. W. Hill, R. J. Mark, M. C. Kimber, J. Org. Chem. 75 (2010) 5406-5409. (r) A. N. Duncan, R. A. Widenhoefer, Synlett (2010) 419-422. (s) K. Aikawa, M. Kojima, K. Mikami, Angew. Chem. Int. Ed. 48 (2009) 6073-6077. (t) 
X. Zeng, M. Soleilhavoup, G. Bertrand, Org. Lett. 11 (2009) 3166-3169. (u) A. M. Manzo, A. D. Perboni, G. Broggini, M. Rigamonti, Tetrahedron Lett. 50 (2009) 4696-4699. (v) X. Zeng, G. D. Frey, S. Kousar, G. Bertrand, Chem. Eur. J. 15 (2009) 3056-3060. (w) N. Nishina, Y. Yamamoto, Tetrahedron 65 (2009) 1799-1808. (x) V. Lavallo, G. D. Frey, B. Donnadieu, M. Soleihavoup, G. Bertrand, Angew. Chem. Int. Ed. 47 (2008) 52245228. (y) N. Nishina, Y. Yamamoto, Tetrahedron Lett. 49 (2008) 4908-4911. (z) R. E. Kinder, Z. Zhang, R. A. Widenhoefer, Org. Lett. 10 (2008) 3157-3159. (aa) V. Gandon, G. Lemière, A. Hours, L. Fensterbank, M. Malacria, Angew. Chem. Int. Ed. 47 (2008) 7534-7538. (ab) Z. Zhang, C. F. Bender, R. A. Widenhoefer, J. Am. Chem. Soc. 129 (2007) 14148-14149. (ac) G. L. Lalonde, B. D. Sherry, E. J. Kang, F. D. Toste, J. Am. Chem. Soc. 129 (2007) 2452-2453. (ad) G. L. Hamilton, E. J. Kang, M. Mba, F. D. Toste, Science 317 (2007) 496-499. (ae) N. Nishina, Y. Yamamoto, Synlett (2007) 1767-1770. (af) Z. Zhang, C. F. Bender, R. A. Widenhoefer, Org. Lett. 9 (2007) 2887-2889. (ag) N. Nishina, Y. Yamamoto, Angew. Chem. Int. Ed. 45 (2006) 3314-3317. (ah) Z. Zhang, C. Liu, R. E. Kinder, X. Han, H. Quian, R. A. Widenhoefer, J. Am. Chem. Soc. 128 (2006) 9066-9073.

[10] Examples of gold catalysed hydroamination of dienes: (a) N. D. Shapiro, V. Rauniyar, G. L. Halmiton, J. Wu, F. D. Toste, Nature Chem. 470 (2011) 245-250. (b) I. Krossing, Angew. Chem. Int. Ed. 50 (2011) 1157611578. (c) O. Kanno, W. Kuriyama, J. Z. Wang, F. D. Toste, Angew. Chem. Int. Ed. 50 (2011) 9919-9922. (d) R. A. Sanguramath, A. Rajashekharaya, T. N. Hooper, C. P. Butts, M. Green, J. E. McGrady, C. E. Russel, Angew. Chem. Int. Ed. 50 (2011) 7592-7595. (e) P. Kothandaraman, C. H. Huang, D. Susanti, W. D. Rao, P. W. H. Chan, Chem. Eur. J. 17 (2011) 10081-10088. (f) D. B. Ramachary, V. V. Narayana, Eur. J. Org. Chem. (2011) 3514-3522. (g) X. Giner, P. Trillo, C. Nájera, J. Organomet. Chem. 696 (2010) 357-361. (h) M. C. P. Yeh, H. F. Pai, Z. J. Lin, B. R. Lee, Tetrahedron 65 (2009) 4789-4794. (i) X. Giner, C. Nájera, Org. Lett. 10 (2008) 2919-2922. (j) C. Brouwer, C. He, Angew. Chem. Int. Ed. 45 (2006) 1744-1747.

[11] a) H. Teller, M. Corbet, L. Mantilli, G. Gopakumar, R. Goddard, W. Thiel, A. Fürstner, J. Am. Chem. Soc. 134 (2012) 15331-15342. b) For a discussion of the basic problem, see: A. S. K. Hashmi, Nature 449 (2007) $292-293$.

[12] M. A. Carvajal, J. J. Novoa, S. Alvarez, J. Am. Chem. Soc. 126 (2004) 1465-1477.

[13] (a) M. C. Gimeno, A. Laguna, Chem. Rev. 97 (1997) 511-522. (b) H. Ito, T. Saito, T. Miyahara, C. Zhong, M. Sawamura, Organometallics 28 (2009) 4829-4840. (c) H. Ito, K. Takagi, T. Miyahara, M. Sawamura, Org. Lett. 7 (2005) 3001-3004. (d) C. Khin, A. S. K. Hashmi, F. Rominger, Eur. J. Inorg. Chem. (2010) 10631069. 
[14] (a) Z. Li, J. Zhang, C. Brouwer, C. G. Yang, N. W. Reich, C. He, Org. Lett. 8 (2006) 4175-4178. (b) W. J. Shi, Y. Liu, P. Butti, A. Togni, Adv. Synth. Catal. 349 (2007) 1619-1623.

[15] (a) Z. Zhang, C. Liu, R. E. Kinder, X. Han, H. Quian, R. A. Widenhoefer, J. Am. Chem. Soc. 128 (2006) 9066-9073. (b) N. T. Patil, L. M. Lutete, N. Nishina, Y. Yamamoto, Tetrahedron Lett. 47 (2006) 4749-4751. (c) N. Nishina, Y. Yamamoto, Angew. Chem. Int. Ed. 45 (2006) 3314-3317. (d) N. Nishina, Y. Yamamoto, Synlett (2007) 1767-1770. (e) N. Nishina, Y. Yamamoto, Tetrahedron Lett. 49 (2008) 4908-4911. (f) N. Nishina, Y. Yamamoto, Tetrahedron 65 (2009) 1799-1808. (g) V. Lavallo, G. D. Frey, B. Donnadieu, M. Soleilhavoup, G. Bertrand, Angew. Chem. Int. Ed. 47 (2008) 5224-5228. (h) X. Zeng, M. Soleilhavoup, G. Bertrand, Org. Lett. 11 (2009) 3166-3169. (i) R. Kinjo, B. Donnadieu, G. Bertrand, Angew. Chem. Int. Ed. 50 (2011) 5560-5563. (j) P. T. Patil, Chem. Asian. J. 7 (2012) 2186-2194.

[16] (a) M. W. Johnson, S. L. Shevick, F. D. Toste, R. G. Bergman, Chem. Sci. 4 (2013) 1023-1027. (b) G. Klatt, R. Xu, M. Pernpointner, L. Molinari, T. Q. Hung, F. Rominger, A. S. K. Hashmi, H. Köppel, Chem. Eur. J. 19 (2013) 3954-3961.

[17] (a) G. Kovács, G. Ujaque, A. Lledós, J. Am. Chem. Soc. 130 (2008) 853-864. (b) G. Kovács, A. Lledós, G. Ujaque, Organometallics 29 (2010) 5919-5926.

[18] R. L. LaLonde, W. E. Brenzovich, D. Benitez, E. Tkatchouk, K. Kelley, W. A. Goddard III, F. D. Toste, Chem. Sci. 1 (2010) 226-233.

[19] (a) T. J. Brown, D. Weber, M. Gagné, R. A. Widenhoefer, J. Am. Chem. Soc. 134 (2012) 9134-9137. (b) K. E. Roth, S. A. Blum, Organometallics 29 (2010) 1712-1716. (c) Y. Shi, K. E. Roth, S. D. Ramgren, S. A. Blum, J. Am. Chem. Soc. 131 (2009) 18022-18023.

[20] B. N. Nguyen, L. A. Adrio, E. M. Barreiro, J. B. Brazier, P. Haycock, K. K. Hii, M. Nachtegaal, M; A. Newton, J. Szalchetko, Organometallics 31 (2012) 2395-2402.

[21] Phosphoramidite ligands in asymmetric gold catalysis: (a) M. P. Muñoz, J. Adrio, J. C. Carretero, A. M. Echavarren, Organometallics 24 (2005) 1293-1300. (b) I. Alonso, B. Trillo, F. López, S. Montserrat, G. Ujaque, L. Castedo, A. Lledós, J. L. Mascareñas, J. Am. Chem. Soc. 131 (2009) 13020-13030. (c) H. Teller, S. Flügge, R. Goddard, A. Fürstner, Angew. Chem. Int. Ed. 49 (2010) 1949-1953. (d) A. Z. Gonzáles, F. D. Toste, Org. Lett. 12 (2010) 200-203. (e) A. Z. González, D. Benitez, E. Tkatchouk, W. A. Goddard, F. D. Toste, J. Am. Chem. Soc. 133 (2011) 5500-5507. (f) I. Alonso, H. Faustino, F. López, J. L. Mascareñas, Angew. Chem. Int. Ed. 50 (2011) 11496-11500. (g) S. Suarez-Pantiga, C. Hernandez-Diaz, E. Rubio, J. M. Gonzalez, Angew. Chem. Int. Ed. 51 (2012) 11552-11555. (h) H. Faustino, I. Alonso, J. L. Mascareñas, F. López, Angew. Chem. 
Int. Ed. 52 (2013) 6526-6530. (i) G. H. Li; W. Zhou, X. X. Li, Q. W. Bi, Z. Wang, Z. G. Zhao, W. X. Hu, Z. Chen, Chem. Commun. 49 (2013) 4770-4772.

[22] Diaminocarbene ligands in asymmetric gold catalysis: (a) R. Corberan, J. Ramírez, M. Poyatos, E. Peris, E. Fernandez, Tetrahedron: Asymmetry 17 (2006) 1759-1762. (b) Y. Matsumoto, K. Tomioka, Tetrahedron Lett. 47 (2006) 5843-5846. (c) Y. Matsumoto, K. Yamada, K. Tomioka, J. Org. Chem. 73 (2008) 4578-4581. (d) N. Bongers, N. Krause, Angew. Chem., Int. Ed. 47 (2008) 2178-2181. (e) K. B. Selim, Y. Matsumoto, K. Yamada, K. Tomioka, Angew. Chem., Int. Ed. 48 (2009) 8733-8735. (f) Y. Matsumoto, K. B. Selim, H. Nakanishi, K. Yamada, Y. Yamamoto, K. Tomioka, Tetrahedron Lett. 51 (2010) 404-407. (g) S. Sengupta, X. Shi, ChemCatChem 2 (2010) 609-619. (h) C. Bartolome, D. García-Cuadrado, Z. Ramiro, P. Espinet, Inorg. Chem. 49 (2010) 9758-9764. (i) K. Wilckens, D. Lentz, C. Czekelius, Organometallics 30 (2011) 1287-1290. (j) W. Wang, J. Yang, F. Wang, M. Shi, Organometallics 30 (2011) 3859-3869. (k) J. Yang, R. Zhang, W. Wang, Z. Zhang, M. Shi, Tetrahedron: Asymmetry 22 (2011) 2029-2038. (l) K. B. Selim, H. Nakanishi, Y. Matsumoto, Y. Yamamoto, K. Yamada, K. Tomioka, J. Org. Chem. 76 (2011) 1398-1408. (m) A. Pradal, P. Y. Toullec, V. Michelet, Synthesis (2011) 1501-1514. (n) Y. M. Wang, C. N. Kuzniewski, V. Rauniyar, C. Hoong, F. D. Toste, J. Am. Chem. Soc. 133 (2011) 12972-12975. (o) K. Yamada, Y. Matsumoto, K. B. Selim, Y. Yamamoto, K. Tomioka, Tetrahedron 68 (2012) 4159-4165. (p) S. Handa, L. M. Slaughter, Angew. Chem. Int. Ed. 51 (2012) 2912-2915. (q) J. Francos, F. Grande-Carmona, H. Faustino, J. Iglesias-Sigüenza, E. Díez, I. Alonso, R. Fernández, J. M. Lassaletta, F. López, J. L. Mascareñas, J. Am. Chem. Soc. 134 (2012) 14322-14325. (r) P. Gu, Q. Xu, M. Shi, Tetrahedron Lett. 55 (2014) 577-584.

[23] (a) Y. Matsumoto, K. I. Yamada, K. Tomioka, J. Org. Chem. 73 (2008) 4578-4581. (b) Y. Matsumoto, K. B. Selim, H. Nakanishi, K. I. Yamada, Y. Yamamoto, K. Tomioka, Tetrahedron Lett. 51 (2010) 404-407. (c) K. B. Selim, Y. Matsumoto, K. Yamada, K. Tomioka, Angew. Chem. Int. Ed. 48 (2009) 8733-8735.

[24] C. Michon, F. Medina, M.-A. Abadie, F. Agbossou-Niedercorn Organometallics 32 (2013) 5589-5600.

[25] (a) R. Sallio, S. Lebrun, N. Schifano-Faux, J. F. Goossens, F. Agbossou-Niedercorn, E. Deniau, C. Michon, Synlett (2013) 1785-1790. (b) F. Medina, N. Duhal, C. Michon, F. Agbossou-Niedercorn, Comptes Rendus Chimie 16 (2013) 311-317. (c) F. Medina, C. Michon, F. Agbossou-Niedercorn, Eur. J. Org. Chem. (2012) 6218-6227. (d) C. Michon, F. Medina, F. Capet, P. Roussel, F. Agbossou-Niedercorn, Adv. Synth. Catal. 352 (2010) 3293-3305. (e) J. J Brunet, D. Neibecker, F. Agbossou, S. S. Radhey, J. Mol. Catal. 87 (1994) 223230. 
[26] (a) A. Guérinot, W. Fang, M. Sircoglou, C. Bour, S. Bezzenine-Lafollée, V. Gandon Angew. Chem. Int. Ed. 52 (2013) 5848-5852. (b) A. Homs, I. Escofet, A. M. Echavarren, Org. Lett. 15 (2013) 5782-5785. (c) Y. Tang, B. Yu, RSC Adv. 2 (2012) 12686-12689. (d) D. Wang, R. Cai, S. Sharma, J. Jirak, S. K. Thummanapelli, N. G. Akhmedov, H. Zhang, X. Liu, J. L. Petersen, X. Shi, J. Am. Chem. Soc. 134 (2012) 9012-9019. (e) D. Weber, M. R. Gagné Org. Lett. 11 (2009) 4962-4965.

[27] (a) T. R. Wu, L. Shen, J. M. Chong, Org. Lett. 6 (2004) 2701-2704. (b) R. Singh, C. Czekelius, R. R. Schrock, P. Müller, A. H. Hoveyda, Organometallics 26 (2007) 2528-2539. (c) R. I. Storer, D. E. Carrera, Y. Ni, D. W. C. MacMillan, J. Am. Chem. Soc. 128 (2006) 84-86. (q) Y. L. Zhang, F. Zhang, W. J. Tang, Q. L. Wu, Q. H. Fan, Synlett 8 (2006) 1250-1254. (e) A. Mercier, X. Urbaneja, W. C. Yeo, P. D. Chaudhuri, G. R. Cumming, D. House, G. Bernardinelli, E. P. Kündig, Chem. Eur. J. 16 (2010) 6285-6299. (f) P. Wipf, J. K. Jung, J. Org. Chem. 65 (2000) 65, 6319-6337.

[28] S. Masamune, W. Choy, J. S. Petersen, L. R. Sita, Angew. Chem. Int. Ed. 24 (1985) 1-30.

[29] For examples of Thorpe-Ingold effect in hydroamination of alkenes: (a) A. Zulys, M. Dochnahl, D. Hollmann, K. Löhnwitz, J.-S. Herrmann, P. W. Roesky, S. Blechert, Angew. Chem. Int. Ed. 44 (2005) 77947798. (b) J. Koller, R. G. Bergman Chem. Commun. 46 (2010) 4577-4579.

[30] T. N. Hooper, C. P. Butts, M. Green, M. F. Haddow, J. E. McGrady, C. A. Russel, Chem. Eur. J. 15 (2009) 12196-12200.

[31] (a) W. E. Buschmann, J. S. Miller, Inorganic Syntheses 33 (2002) 83-84; (b) N. A. Yakelis, R. G. Bergman, Organometallics 24 (2005) 3579-3581; (c) M. Brookhart, B. Grant, A. F. Volpe, Organometallics 11 (1992) 3920-3922.

[32] (a) M. Klussmann, L. Ratjen, S. Hoffmann, V. Wakchaure, R. Goddard, B. List, Synlett (2010) 21892192; (b) G. L. Hamilton, E. J. Kang, M. Mba, F. D. Toste, Science 317 (2007) 496-499.

[33] (a) Y. Kashiwame, S. Kuwata , T. Ikariya Organometallics 31 (2012) 8444-8455; (b) T. Kondo, T. Okada, T. Mitsudo J. Am. Chem. Soc. 124 (2002) 186-187.

[34] M. R. Crimmin, M. Arrowsmith, A. G. M. Barrett, I. J. Casely, M. S. Hill, P. A. Procopiou J. Am. Chem. Soc. 131 (2009) 9670-9685.

[35] F. E. Michael, B. M. Cochran, J. Am. Chem. Soc. 128 (2006) 4246-4247. 